\title{
Plasmonic Photocatalysts for Microbiological Applications
}

\author{
Maya Endo-Kimura and Ewa Kowalska *D \\ Institute for Catalysis, Hokkaido University, N21 W10, Sapporo 001-0021, Japan; m_endo@cat.hokudai.ac.jp \\ * Correspondence: kowalska@cat.hokudai.ac.jp
}

Received: 26 June 2020; Accepted: 22 July 2020; Published: 23 July 2020

check for updates

\begin{abstract}
Wide-bandgap semiconductors modified with nanostructures of noble metals for photocatalytic activity under vis irradiation due to localized surface plasmon resonance (LSPR), known as plasmonic photocatalysts, have been intensively investigated over the last decade. Most literature reports discuss the properties and activities of plasmonic photocatalysts for the decomposition of organic compounds and solar energy conversion. Although noble metals, especially silver and copper, have been known since ancient times as excellent antimicrobial agents, there are only limited studies on plasmonic photocatalysts for the inactivation of microorganisms (considering vis-excitation). Accordingly, this review has discussed the available literature reports on microbiological applications of plasmonic photocatalysis, including antibacterial, antiviral and antifungal properties, and also a novel study on other microbiological purposes, such as cancer treatment and drug delivery. Although some reports indicate high antimicrobial properties of these photocatalysts and their potential for medical/pharmaceutical applications, there is still a lack of comprehensive studies on the mechanism of their interactions with microbiological samples. Moreover, contradictory data have also been published, and thus more study is necessary for the final conclusions on the key-factor properties and the mechanisms of inactivation of microorganisms and the treatment of cancer cells.
\end{abstract}

Keywords: plasmonic photocatalyst; vis-responsive material; antimicrobial effect; antifungal properties; antiviral effect; disinfection; bacteriocyte; noble metal; LSPR; environmental purification

\section{Introduction}

Clean water and sanitation, one of Sustainable Development Goals (adopted in United Nations summit in 2015), are highly necessary to achieve a better and sustainable society. Accordingly, the efficient technologies of water and wastewater treatment, also being accessible to everyone, have been considered as an urgent issue. It has been assumed that, in the world, one in three people do not have access to clean water for drinking and two out of five cannot wash hands properly, due to a lack of basic washing facilities [1]. Moreover, nearly 1000 children die every day due to diarrheal diseases, connected with contaminated water [1]. The coronavirus disease 2019/2020 (COVID-19) has unfortunately clarified the importance of sanitation, hygiene and adequate access to clean water for preventing the spear of infectious disease. In developing countries with insufficient water purification facilities, people must use water contaminated with feces, heavy metals, inorganic and organic pollutants, and pathogenic microorganisms. Waterborne pathogens might cause acute (e.g., diarrhea) and chronic (e.g., infectious hepatitis, cancer) health effects. Furthermore, not only slight symptoms (e.g., diarrhea), but also serious ones have been reported, such as cholera, hemolytic-uremic syndrome by Escherichia coli (E. coli) O157, and even cancer [2]. Whereas, even in developed countries, despite the fact that chemical contamination is well monitored and controlled [3-5], unpredicted outbreaks of pathogenic microorganisms have also occurred. It should be pointed out that, not only imported 
infectious diseases (e.g., typhus (caused by Salmonella enterica serovar Typhi, Salmonella enterica serovar Paratyphi A or Rickettsia prowazekii) and polio (Poliovirus)), but also illnesses caused by indigenous microorganisms via fecal-oral route (e.g., contaminated drinking water, or pools and public spas), have been observed, including a cryptosporidiosis by Cryptosporidium species (sp.), which is resistant to chlorination, and a Legionnaires' disease by Legionella sp.

In association with the development of society, water demand is increasing for both domestic and industrial applications, but unfortunately water sources are limited. Therefore, it is necessary to reuse water without additional loads for the environment. In developed countries, the treatment of (waste) water is carried out by combinations of various methods, including precipitation, filtration (e.g., membrane technologies), adsorption, microbial purification (by activated sludge), oxidation (ozonization, chlorination, advanced oxidation technologies (AOPs)), depending on the kind and levels of contamination (water and municipal or industrial wastewater). Chlorination is commonly used for various types of wastewater and water, mainly as a final step of water disinfection, because chlorine can completely inactivate some microorganisms. However, it might also negatively influence aquatic organisms, due to the ability to bind to nitrogen and organic compounds, resulting in the formation of highly toxic by-products (e.g., trihalomethane). In addition, chlorine disinfection has a low effect on some pathogenic protozoa (e.g., Cryptosporidium sp.) and viruses (e.g., norovirus). Similarly, UV-irradiation and ozonization both possess advantages and disadvantages (i.e., high efficiency against microorganisms, including viruses (UV and ozone), but low sensitivity to some viruses, such as adenovirus, no residual effect (UV), own toxicity, and the formation of toxic by-products (ozone)). Therefore, clean, inexpensive, and environmentally friendly methods for water purification and wastewater treatment are highly needed. Moreover, point-of-use water treatment methods are strongly desired in many areas that are inaccessible to municipal water treatment technologies.

Among oxidation methods, AOPs have been indicated as highly efficient and are recommended, due to the in situ generation of powerful reactive oxygen species (ROS), including hydroxyl radicals $\left(\mathrm{HO}^{\bullet}\right)$. However, many of them involve high investments and operating costs. Heterogenous photocatalysis on semiconductor oxides also belong to AOPs, since under irradiation the semiconductor is excited, and generates charge carriers (i.e., electrons in the conduction band (CB) and holes in the valence band (VB)) might form ROS in the presence of oxygen and water. There is only one main limitation of heterogenous photocatalysis as AOPs, i.e., low activity under solar radiation because the most active photocatalysts have wide bandgap, and thus must be excited with UV, being only ca. 3-4\% of solar spectrum. Accordingly, vis-responsive materials have been intensively investigated for efficient photocatalysis under real solar conditions, including plasmonic photocatalysts (i.e., wide-bandgap semiconductor modified with plasmonic NPs, such as gold, silver, platinum, and copper). Although, plasmonic photocatalysis is a new topic, various reports on plasmonic photocatalysts have already been published, including some on antimicrobial activity. Accordingly, this review summarizes and discusses the available literature on plasmonic photocatalysis for microbial inactivation. Additionally, some other biological applications of plasmonic photocatalysts are presented.

\section{Plasmonic Photocatalysis}

Titanium(IV) oxide (titania, $\mathrm{TiO}_{2}$ ) is one of the most studied semiconductor photocatalysts, due to various advantages, such as high photocatalytic activity, stability, abundance, inexpensiveness and low toxicity (except for the toxicity of nanomaterials [6]). It should be pointed out that photocatalysis has been considered as one of the best methods for environmental purification, since additional chemical compounds, such as strong oxidants (ozone, hydrogen peroxide $\left(\mathrm{H}_{2} \mathrm{O}_{2}\right)$, chlorine [7-14]) are not introduced into the environment $[15,16]$, and the energy consumption is much lower than that in other AOPs (e.g., wet air oxidation [17], supercritical water oxidation [18], or $\mathrm{H}_{2} \mathrm{O}_{2} / \mathrm{UV}-\mathrm{C}$ [19]). However, titania has wide bandgap of ca. 3.0-3.2 eV (depending on the crystalline form), and thus it must be excited by UV-light irradiation (absorption edge at ca. $385-410 \mathrm{~nm}$ ). The principle of heterogeneous photocatalysis might be presented by the band-structure model. In brief, irradiation 
with higher or equal energy than the bandgap excites electrons from VB to $\mathrm{CB}$, generating positive holes in VB. Generated electrons $\left(\mathrm{e}^{-}\right)$and holes $\left(\mathrm{h}^{+}\right)$reduce and oxidize adsorbed substances (e.g., organic compounds, water), respectively. When electrons and holes react with water and oxygen, $\mathrm{ROS}$ are formed (e.g., hydroxyl radical $\left(\mathrm{HO}^{\bullet}\right)$, superoxide anion radical $\left(\mathrm{O}_{2}{ }^{\bullet-}\right)$ and $\left.\mathrm{H}_{2} \mathrm{O}_{2}\right)$. On the other hand, charge carriers $\left(\mathrm{e}^{-} / \mathrm{h}^{+}\right)$might recombine either in the bulk or on the surface of titania, which is typical for all semiconductors, resulting in a lower than expected efficiency of photocatalytic reactions. Indeed, the quantum yields of photocatalytic reactions are usually much lower than $100 \%$ (e.g., $4 \%$ has been reported for the generation of hydroxyl radicals [20]). In addition, titania cannot absorb a large fraction of solar light, which contains only about $3-5 \%$ of UV, due to its wide bandgap. Therefore, in order to improve the photocatalytic activity of titania, a number of studies have been performed, focusing on the utilization of visible light and the suppression of charge carrier recombination (e.g., surface modification, doping (nitrogen, sulfur, carbon and self-doping) and preparation of coupled nanostructures [21-30]). Although titania doping has resulted in the appearance of vis activity, dopants could be recombination centers, and thus decreasing photocatalytic activity under UV irradiation.

Modification with noble metal nanoparticles (NMNPs) (e.g., Ag, Au, Pt, Pd) seems to be the most promising, since it is well known that NM (noble metal) works as an electron sink under UV irradiation, inhibiting the $\mathrm{e}^{-} / \mathrm{h}^{+}$recombination [31-33]. When NMNPs are in a contact with semiconductors, a Schottky barrier is established, hindering the charge carriers' recombinations [34]. On the other hand, under vis irradiation, titania is activated by the plasmonic properties of NM (plasmonic photocatalysis) [35,36]. NM-modified titania photocatalysts show localized surface plasmon resonance (LSPR), and obtained vis response depends on the kind of metal (e.g., LSPR for small spherical NPs of $\mathrm{Ag}, \mathrm{Cu}$, and $\mathrm{Au}$ at ca. 420, 600, and $550 \mathrm{~nm}$, respectively), their morphology, size, and environment (refractive index of medium). For example, Au nanospheres of several nanometers show LSPR at ca. $520 \mathrm{~nm}$ and bathochromic shift has been observed with an increase in the particle size [37]. A similar shift has been obtained for nanorods with an increase in their aspect ratio [37]. The most important findings by action spectrum analysis (action spectra resembling absorption spectra) confirm that plasmon resonance is responsible for vis-activity of wide-bandgap semiconductors $[35,38,39]$.

Three main mechanisms of plasmonic photocatalysis under vis irradiation have been proposed (i.e., (i) charge transfer; (ii) energy transfer; (iii) plasmonic heating), as follows:

(i) Under irradiation with LSPR wavelength, NMNPs absorb the photons and "hot" electrons are transferred to the $\mathrm{CB}$ of the semiconductor. The oxygen on the semiconductor surface is reduced by the electron and the resultant electron-deficient NMNP might oxidize substances to recover to its original metallic state. For example, Tian et al. have shown an electron transfer from Au to titania and from electron donor to $\mathrm{Au}$ by the observation of anodic and cathodic photocurrents in $\mathrm{Au} / \mathrm{TiO}_{2} /$ indium tin oxide (ITO) and $\mathrm{TiO}_{2} / \mathrm{Au} / \mathrm{ITO}$, respectively $[35,40,41]$.

(ii) Plasmon resonance energy transfer (PRET) might occur for energy overlapping between plasmonic metals and semiconductors (LSPR band of metals and the band gap absorption of semiconductors) (e.g., Au NPs (LSPR of ca. $2.2 \mathrm{eV}$ ) and $\mathrm{Cu}_{2} \mathrm{O}$ (ca. $2.2 \mathrm{eV}$ ) [42]). Accordingly, although energy transfer is not expected for Au-modified titania, due to the wide band gap of titania (ca. 3-3.2 eV), PRET has been claimed for Au-modified nitrogen-doped titania, due to the generation of new energy levels (inside bandgap) [43]. Additionally, PRET has already been proposed for application in biomolecular imaging, e.g., cytochrome c in living cells [44].

(iii) Plasmonic heating has also been considered as one of the key factors for photocatalytic activities (e.g., oxidation of $\mathrm{HCHO}$ [45], degradation of methylene blue [46], reduction of 4-nitrobenzenethiol [47] and $\mathrm{CO}_{2}$ reduction [48]). According to Chen et al., the plasmon-induced heating on Au NPs might activate organic molecules to induce their oxidation [45]. Although other studies have claimed that energy release by plasmonic heating is insufficient for chemical bond cleavage, it seems that local 
heating must be important for microorganism killing, as microorganisms are highly sensitive to any environmental changes.

As described above, plasmonic photocatalysts induce redox reactions of organic compounds on the surface of NMNP and titania. However, those photocatalysts do not possess as strong oxidation abilities as that of titania under UV irradiation (2-3 orders in magnitude lower photocatalytic activity under vis than that under UV have been reported [33,38,39]), due to the low energy of visible light and fast charge carrier recombination (i.e., back electron transfer to NMNPs (e.g., $\mathrm{NM} \rightarrow \mathrm{TiO}_{2} \rightarrow \mathrm{NM}$ ) [49]). Therefore, various studies on the improvement of the photocatalytic activities of plasmonic photocatalysts have been proposed (e.g., modification of NMNPs' morphology [50], heterojunction with other semiconductors/complexes [33,51,52], deposition of second NMNPs [53-55], the addition of adsorbents [56-58], and morphology modifications of semiconductor [49,59-61]).

\section{Heterogeneous Photocatalysis for Microbiological Purposes}

The first report on microbial inactivation by heterogeneous photocatalysis was published by Matsunaga et al. In 1985 [62]. It was found that irradiated titania and platinum (Pt)-loaded titania could sterilize yeast, Gram-positive and Gram-negative bacteria, and algae, due to the photoelectrochemical oxidation of coenzyme A (CoA). Accordingly, it has been proposed that the oxidation of CoA has inhibited respiratory activity, inducing the death of cells [62-64]. The bacterial killing mechanisms by titania photocatalysts has been summarized comprehensively by Markowska-Szczupak et al. [65], pointing to three main pathways (i.e., peroxidation of cell membrane phospholipids [66,67], direct DNA damage [64], and the oxidation of CoA [62]). All these mechanisms are attributed to ROS formation from oxygen and water by reduction/oxidation reactions on irradiated titania. It has been reported that mainly $\mathrm{HO}^{\bullet}$ radicals, the most active ROS, participate in bactericidal effect $[4,68]$, despite their short half-lifetime. Moreover, other $\mathrm{ROS}$ (e.g., $\mathrm{O}_{2}{ }^{\bullet-}$ and $\mathrm{H}_{2} \mathrm{O}_{2}$ ) and direct redox reactions by charge carriers (surface $\mathrm{e}^{-} / \mathrm{h}^{+}$) have also been proposed for bacterial inactivation [61,69]. In addition, Du et al. have found that proteins are an initial target of radicals $\left(\mathrm{HO}^{\bullet}\right)$, preceding lipids and DNA [70]. On the other hand, some bacteria possess their protection system against oxidation stress (i.e., forming ROS scavenger enzymes, such as superoxide dismutase (SOD) and catalase (CAT)). SOD enzymes might decompose ROS to $\mathrm{H}_{2} \mathrm{O}_{2}$ and $\mathrm{O}_{2}$, and not only in the cytoplasm, but also on the surface of cells [71,72]. Generated $\mathrm{H}_{2} \mathrm{O}_{2}$ is further decomposed to $\mathrm{O}_{2}$ and $\mathrm{H}_{2} \mathrm{O}$ by CAT. Importantly, some bacteria secreting CAT might be released outside of cells [73,74], which also might contribute to their resistance against extracellular ROS. For example, it has been found that the levels of SOD and CAT increase during first $30 \mathrm{~min}$ of titania irradiation with UV/vis, and then decrease (after $60 \mathrm{~min}$ ) [75]. According to these changes, the two-step mechanism of bacteria response (Gram-negative E. coli and Gram-positive Staphylococcus epidermidis) has been proposed, where the changes in the enzyme activity during the photocatalytic disinfection might indicate that the defense capacity has been overwhelmed by the rapidly created ROS at the initial stage. The correlation between high content of generated $\mathrm{HO}^{\bullet}$ radicals during $90 \mathrm{~min}$ of irradiation and the loss of enzymatic activity suggests that oxidative stress might act as an important step, in which the photocatalyst induces bacterial death.

Moreover, heat shock proteins protect cells under an oxidative stressed environment [76], and DNA repair enzymes might repair damaged DNA [77]. In addition to enzymes, cell morphology also influences microbial inactivation by photocatalysis. It has been proposed that an inactivation effect of titania photocatalyst against microorganisms might be put in the following order: Gram-negative bacteria $>$ Gram-positive bacteria $>>$ fungi (yeast) $>$ fungi (mold) [24], possibly due to the complexity of cells. Gram-negative bacteria have a thin (ca. $10 \mathrm{~nm}$ ) peptidoglycan layer, whereas the cell walls in Gram-positive bacteria are much thicker (ca. 10-100 nm). Moreover, fungal cells (i.e., eukaryotic organisms), have rigid cell walls, containing chitin, proteins, polysaccharide polymers and lipids [78]. Furthermore, they have nuclear membranes and multicellular structures (except for unicellular organisms). 
It should be pointed out that the intrinsic and surface properties of photocatalysts (e.g., bandgap energy, specific surface area, crystallite/particle size, aggregation, surface charge, defects distribution and impurities content), are also crucial for the overall antimicrobial effect $[49,54,75,79]$. For example, rutile (polymorphic form of titania) has shown much higher activity than anatase (usually the most active titania form) under natural indoor light against mold fungi, probably because of its narrower bandgap, and thus ability to absorb more photons [79]. Moreover, it has been found that sporulation and mycotoxin generation have been highly inhibited by photocatalytic reactions on titania photocatalysts, as exemplarily shown in Figure 1. Interestingly, some fungi could be stimulated by titania presence (i.e., although the growth of Pseudallescheria boydii and Aspergillus versicolor has been highly inhibited by titania and light, the growth of Stachybotrys chartarum has been accelerated by titania). It should be remembered that different fungi species have different water and nutrient demand. Accordingly, adsorbed water and some impurities on the titania surface might either stimulate or inhibit the fungal growth [79].

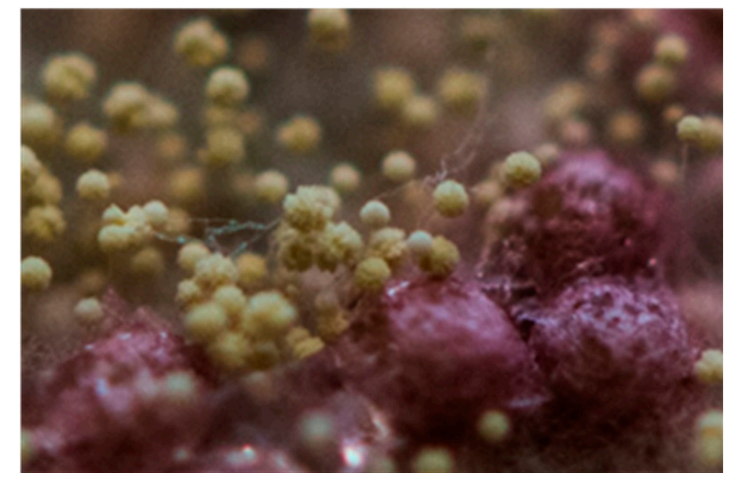

(a)

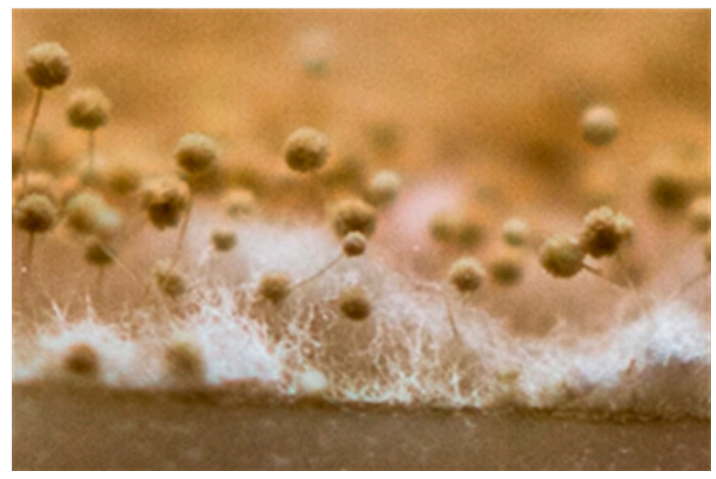

(b)

Figure 1. Images of three-day growth of Aspergillus melleus: (a) in the dark and (b) under irradiation in the presence of commercial titania photocatalyst P25 (after homogenization); adapted with permission (after formatting) from [79]. Copyright (2015) Elsevier.

Various applications of titania photocatalysts for microbial inactivation have already been proposed, including commercialized ones (e.g., the surfaces of equipment/walls covered with titania for efficient sterilization in hospitals). Titania modified with glucose has also been proposed for water disinfection (e.g., by placing concrete plates covered with titania in aqueous reservoirs or disinfecting water in $\mathrm{TiO}_{2} /$ concrete-covered containers used for storage of drinking water or fish farms), as exemplified for a home aquarium in Figure 2a [75]. Other microbiological applications of titania photocatalysts have also been proposed, including for biomedical purposes (e.g., for decomposition of human breast cancer cells (Figure 2b) [80]).

\subsection{Plasmonic Photocatalysts for Inactivation of Microorganisms}

Plasmonic photocatalysts are surely promising candidates as antimicrobial agents. Although there are only several studies on microbial inactivation on plasmonic photocatalysts (i.e., under vis irradiation (not considering activities of NMNP-modified titania tested under UV and in the dark)), high activity is expected, coming from: (i) intrinsic activity of noble metals; (ii) enhanced activity under UV irradiation (inhibition of $\mathrm{e}^{-} / \mathrm{h}^{+}$recombination); (iii) activity under vis irradiation, resulting from the plasmonic activation of wide-bandgap semiconductors. The exemplary effects of the intrinsic properties of NM are described below.

Although the safety of silver for human and animals has been confirmed, it is also known that a slight amount of silver shows remarkable antimicrobial efficiency. Generally, the antibacterial activity of silver is more effective for Gram-negative bacteria than Gram-positive ones, presumably due to the differences in their biological structures. Although, the antimicrobial effect of silver has been 
well-studied, the mechanism of its action is still under discussion. Therefore, different antimicrobial pathways of Ag NPs have been proposed in the literature, as follows:

(1) Adsorption of Ag cations on a negatively charged bacterial cell wall, followed by the collapse of the cell wall and the plasma membrane, and a release of substances outside of the cell, leading to cell lysis and death [81,82];

(2) Interaction with thiol groups of transport and respiratory enzymes that are fatal to the survival of cells, causing the uncoupling of respiration from the synthesis of ATP [83];

(3) Collapse of membrane potential and a leakage of protons, as a result of the destabilization of plasma membrane and de-energization of bacterial cells [84].

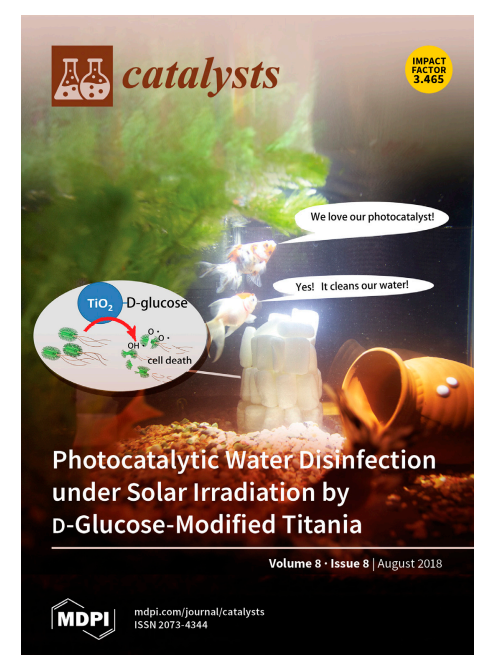

(a)

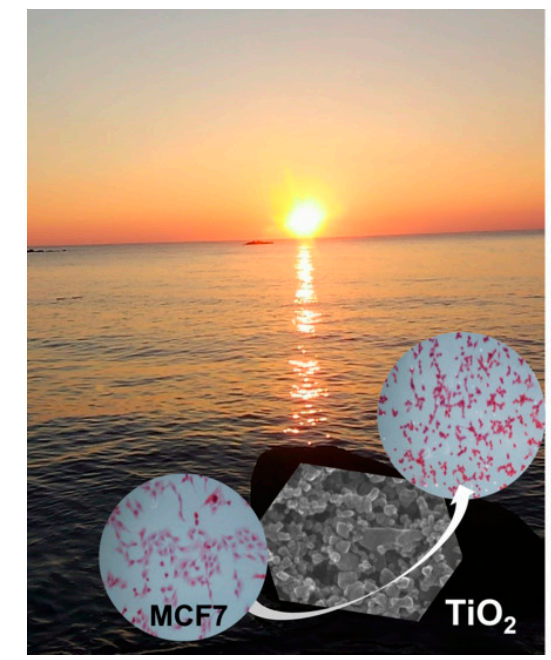

(b)

Figure 2. Examples of possible microbiological applications of titania photocatalysts: (a) modified titania with D-glucose for disinfection of water tanks (journal cover image; https://res.mdpi.com/data/ covers/catalysts/big_cover-catalysts-v8-i8.png) and (b) decomposition of breast adenocarcinoma MCF7 cells (ATCC ${ }^{\circledR}$ HTB-22 ${ }^{\mathrm{TM}}$, breast adenocarcinoma cell line from human) on commercial titania (P25) irradiated with UVA/vis (graphical abstract); adapted with permission from [75] and [80], respectively. Copyright 2018 and 2020, respectively, Creative Commons Attribution.

Accordingly, it has been considered that the release of Ag cations from carrier (free Ag cations in solution/suspension) is important for bactericidal activity [85-89]. For example, it has been reported that the activity of $\mathrm{Ag} / \mathrm{TiO}_{2}$ in the dark is higher than that in the presence of light, due to the instability of $\mathrm{Ag}$ on $\mathrm{TIO}_{2}$ without irradiation (i.e., $\mathrm{Ag}$ release) [85]. In order to obtain the continuous release of $\mathrm{Ag}$ ions from Ag NPs (to keep long-term antimicrobial activities), Ag NPs have been deposited on some supporting materials (e.g., silica [90], clay [91], and zeolite [57]). Silver NPs also possess antimicrobial activities against fungi, algae, and viruses. The proposed mechanism of antivirus action is based on the interaction between Ag NPs and glycoproteins from the virus surface, which induces an inhibition of virus binding to target cells, as well as the possible inhibition of virus replication when viral cells are penetrated by Ag NPs [92,93].

Copper $(\mathrm{Cu})$ is also considered as an excellent purifier, due to its low price and high activity. The proposed bactericidal mechanisms are based on the adsorption of $\mathrm{Cu}$ ions on the surface of bacteria and, subsequently: (1) the structure of surface proteins is denaturated [94], and/or (2) adsorbed $\mathrm{Cu}$ ions induce oxidative stress in bactericidal process [95]. The accumulation of $\mathrm{Cu}$ ions inside bacteria has been reported as the main mechanism of bacteria inactivation by $\mathrm{Cu}$-modified blotting paper (i.e., accumulation of $\mathrm{Cu}$ ions from direct contact with $\mathrm{Cu}$ NPs in the paper [96]). Furthermore, in the case of copper oxides, it has been proposed that $\mathrm{Cu}_{2} \mathrm{O}$ has higher bactericidal activity than $\mathrm{CuO}$ and $\mathrm{Ag}$ [94]. On the other hand, Cu NPs exhibit lower toxicity than Ag NPs against some species of fungi [97]. 
Recently, the bactericidal activity of gold NPs has been proposed, however, it is still under discussion. There are many contradictory reports on the activity of Au NPs (i.e., Au NPs exhibit negligible activity for both Gram-negative and Gram-positive bacteria [98-100], possibly due to a lack of ability to surround bacterial cells [101], and oppositely, high activity [100,102-104]). For size dependence, Zheng et al. have shown that only Au nanoclusters (sub-nanometer size) exhibit bactericidal activity, but NPs (>2 nm) do not [100]. On the contrary, Badwaik et al. have demonstrated that, although 25-nm Au NPs show low activity, larger NPs (60 and 120-nm Au NPs) are highly active [103]. It has been proposed that the bactericidal mechanisms of Au NPs is based on: (i) the ability to change the membrane potential; (ii) inhibition of ATP synthase activities to decrease the ATP level; (iii) inhibition of the subunit of ribosome for tRNA binding and, importantly, all these mechanisms are independent on ROS generation [104]. Moreover, Au NPs possess antifungal activity, depending on the particle size of Au NPs (i.e., activity increase with a decrease in the particle size, due to an increase in the specific surface area of Au NPs, enhancing the interaction between Au and the binding sites of the plasma membrane proteins, and thus resulting in the inhibition of $\mathrm{H}^{+}$-ATPase-mediated proton pumping [105]). Au NPs also show antiviral activity (e.g., inhibition of viral attachment, entry, and cell-to-cell spread [106]).

Therefore, due to the high antimicrobial activity of NMNPs, as described above, various studies on silver- $[57,69,85,89,107-109]$ and copper (and copper oxide)-modified titania have been reported [52,110-112]. Moreover, Au-modified titania has also been investigated, due to high photocatalytic activity (ROS generation), and the ability to disrupt the electron transport in the cells [59]. The proposed mechanisms of microbial inactivation and exemplary applications of plasmonic photocatalysts with antimicrobial properties (summarized in Table 1 for property-governed activity) are briefly discussed in the following paragraphs.

It is widely known that silver-modified titania shows high antimicrobial activity, due to the intrinsic activity of silver in the dark and enhanced activity of titania under irradiation. The release of $\mathrm{Ag}^{+}$, silver adsorption onto bacteria, and ROS generation are important factors for bactericidal action. For example, Castro et al. have suggested that increased $\mathrm{Ag}^{+}$content on the surface of $\mathrm{TiO}_{2}$ by vis pre-irradiation (oxidation of $\mathrm{Ag}^{0}$ to $\mathrm{Ag}^{+}$and $\mathrm{Ag}^{2+}$ ) enhances bacteriostatic activity in the dark [109]. Importantly, not only the inactivation of bacteria, but also the decomposition of bacterial cells is essential as the complete removal of possible allergen [113]. Accordingly, the destruction of bacteria cells (e.g., protoplast formation; Figure 3e) and initiation of their complete decomposition (mineralization), estimated by continuous $\mathrm{CO}_{2}$ evolution (Figure 4), has been observed on $\mathrm{Ag} / \mathrm{TiO}$ photocatalysts only under irradiation (negligible $\mathrm{CO}_{2}$ evolution in the dark due to bacteria breathing), as exemplarily shown in Figures 4 and 5 [114,115].

The importance of ROS generation for the inactivation and decomposition of bacterial cells has been proposed by many researchers (e.g., vis irradiation $(\lambda>420 \mathrm{~nm})$ of $\mathrm{Ag} / \mathrm{AgBr} / \mathrm{TiO}{ }_{2}$ nanotube array causes the oxidative attack of E. coli by $\mathrm{HO}^{\bullet}, \mathrm{O}_{2}{ }^{-}, \mathrm{h}^{+}$, and $\mathrm{Br}^{0}$ from the exterior to the interior, resulting in cell death as the primary mechanism of photo-electrocatalytic (PEC) inactivation (Figure 5) [116]).

Silver-modified $\mathrm{TiO}_{2}$ samples show high antibacterial activity under visible light irradiation (much higher than that in the dark) with complete decomposition of E. coli cells [114,115]. The surface properties of photocatalysts are crucial for the antimicrobial effect and, generally, a decrease in particle sizes results in an increase in activity, due to a larger interface between microorganisms and photocatalysts. Moreover, morphology-controlled titania NPs (e.g., faceted anatase with octahedral shape-octahedral anatase particles (OAP)), which are highly active for the decomposition of organic compounds, also show high antimicrobial activity against bacteria (E. coli) and fungi (Candida albicans) [117]. Interestingly, it has been found that an Ag-modified OAP sample has superior bactericidal activity under visible light than that under UV-vis irradiation (Figure 6), possibly because of Ag oxidation with simultaneous release of Ag cations (an electron transfer from Ag to the $\mathrm{CB}$ of $\mathrm{TiO}_{2}$ under LSPR excitation; in contrast to a reverse electron transfer under UV irradiation (i.e., from $\mathrm{TiO}_{2}$ to $\mathrm{Ag})$ ), and thus free Ag cations might penetrate the cell membrane, resulting in the death of bacteria [117]. 
Similarly, Ye et al. have shown that the flower-like hierarchical $\mathrm{TiO}_{2} / \mathrm{Ag}$ composites with slightly higher activity than spherical ones decompose bacterial cells (both E. coli and Staphylococcus aureus), due to the synergistic effect of the generated ROS and release of Ag ions [118]. On the other hand, the stability of $\mathrm{Ag} / \mathrm{TiON}$ (on polyester) photocatalyst has been shown in repetitive experiments for bacterial inactivation under indoor light, suggesting that leaching of Ag into the environment does not happened [119]. Interestingly, van Grieken et al. have shown that substantial lixiviation of $\mathrm{Ag}\left(\mathrm{Ag}^{+}\right)$ occurs in the dark, increasing the bactericidal activity, but UV irradiation stabilizes Ag deposits [85]. Liga et al. have described that increased virus (bacteriophage MS2) adsorption onto silver sites and leaching of $\mathrm{Ag}^{+}$contribute to virus inactivation [89]. In addition, enhanced ROS generation by Ag-modified titania photocatalysts has correlated with the microbial inactivation under UV-vis irradiation $[69,87,120]$. Swetha et al. have proposed that ROS in large quantity, generated under UV irradiation of nano titania in aqueous medium, might attack the cell membrane, peroxidized the lipid layer with the release of proteins, $\mathrm{K}^{+}$ions, nucleic acids and $\beta$-D-galactosidase [121]. However, it should be pointed out that different mechanisms of photocatalyst activation, and thus different mechanisms of microorganism inactivation should be considered under vis and UV irradiation, i.e., LSPR excitation with possible "hot" electron transfer from $\mathrm{Ag}$ to $\mathrm{TiO}_{2}$ (resulting in more positively charged silver with high possibility of its leakage) and $\mathrm{TiO}_{2}$ excitation with electron transfer to Ag (resulting in less positively charged Ag with lower possibility of leakage), respectively. Interesting data have been found by action spectra analyses (activity depending on the irradiation wavelengths) for titania modified with mono- and bi-metallic Ag and Au NPs, where high stability of $\mathrm{Au} @ \mathrm{Ag} / \mathrm{TiO}_{2}$ photocatalysts under vis irradiation resulted from the possible stabilization of silver by gold (electron transfer from Au to electron-deficient Ag) [122,123].

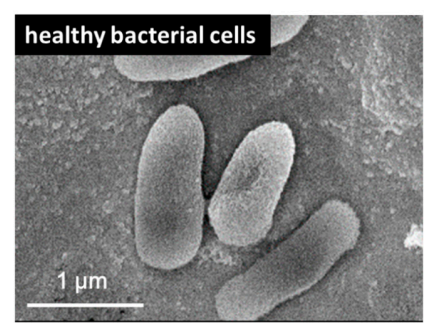

(a)

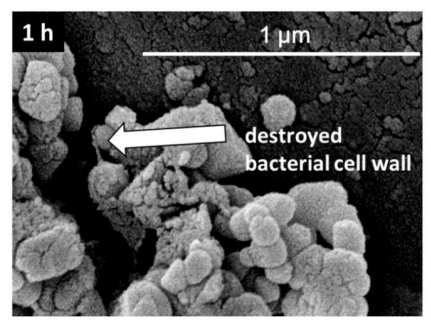

(c)

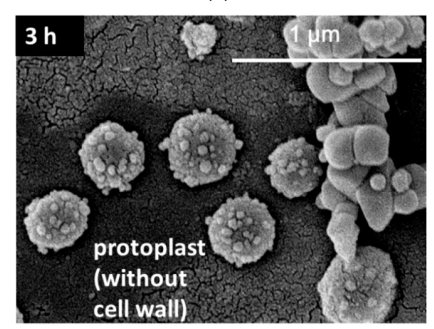

(e)

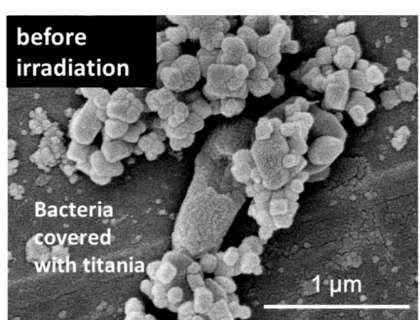

(b)

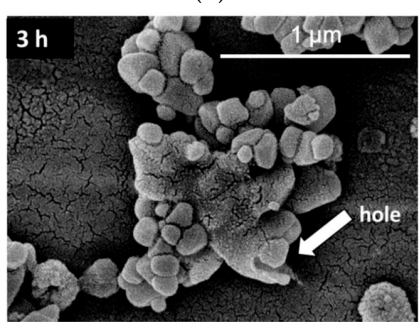

(d)

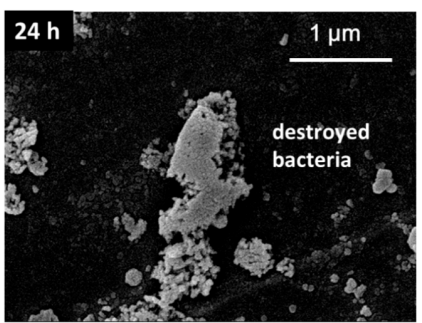

(f)

Figure 3. SEM images of the decomposition of $E$. coli under vis $(\lambda>420 \mathrm{~nm})$ irradiation of $\mathrm{Ag} / \mathrm{TiO}_{2}$ photocatalyst: (a) healthy bacteria cells, (b) bacteria covered with titania before photocatalytic reaction, (c,f) destroyed bacteria cells after: (c) $1 \mathrm{~h},(\mathbf{d}, \mathbf{e}) 3$ hand (f) 24 hof irradiation; adapted with permission from [115]. Copyright 2018, Creative Commons Attribution. 


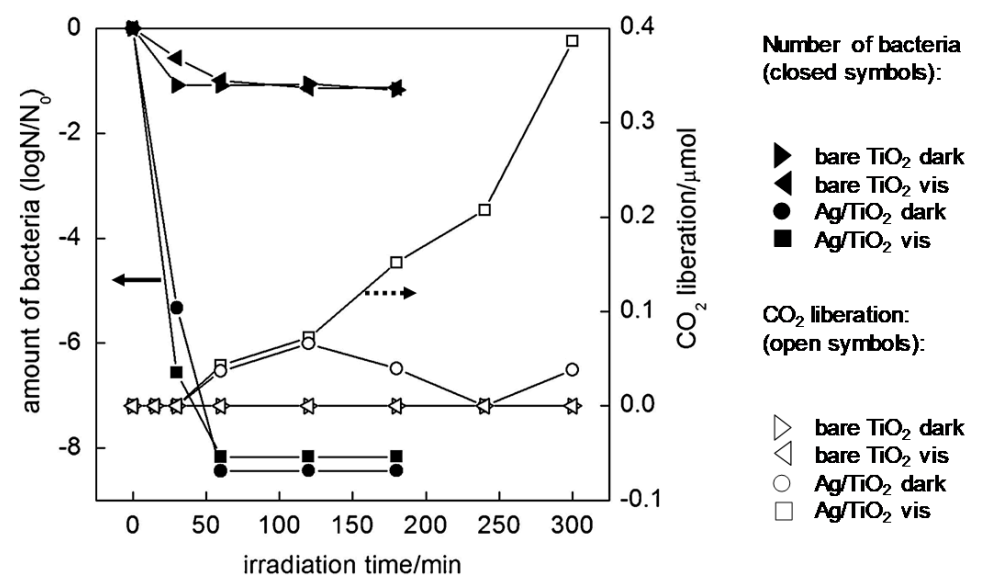

Figure 4. E. coli decomposition presented as a decrease in bacteria number (closed symbols) and $\mathrm{CO}_{2}$ evolution (open symbols), tested in the suspension of titania under vis irradiation $(\lambda>450 \mathrm{~nm})$ and in the dark; adapted with permission (after formatting) from [114]. Copyright 2015 Elsevier.
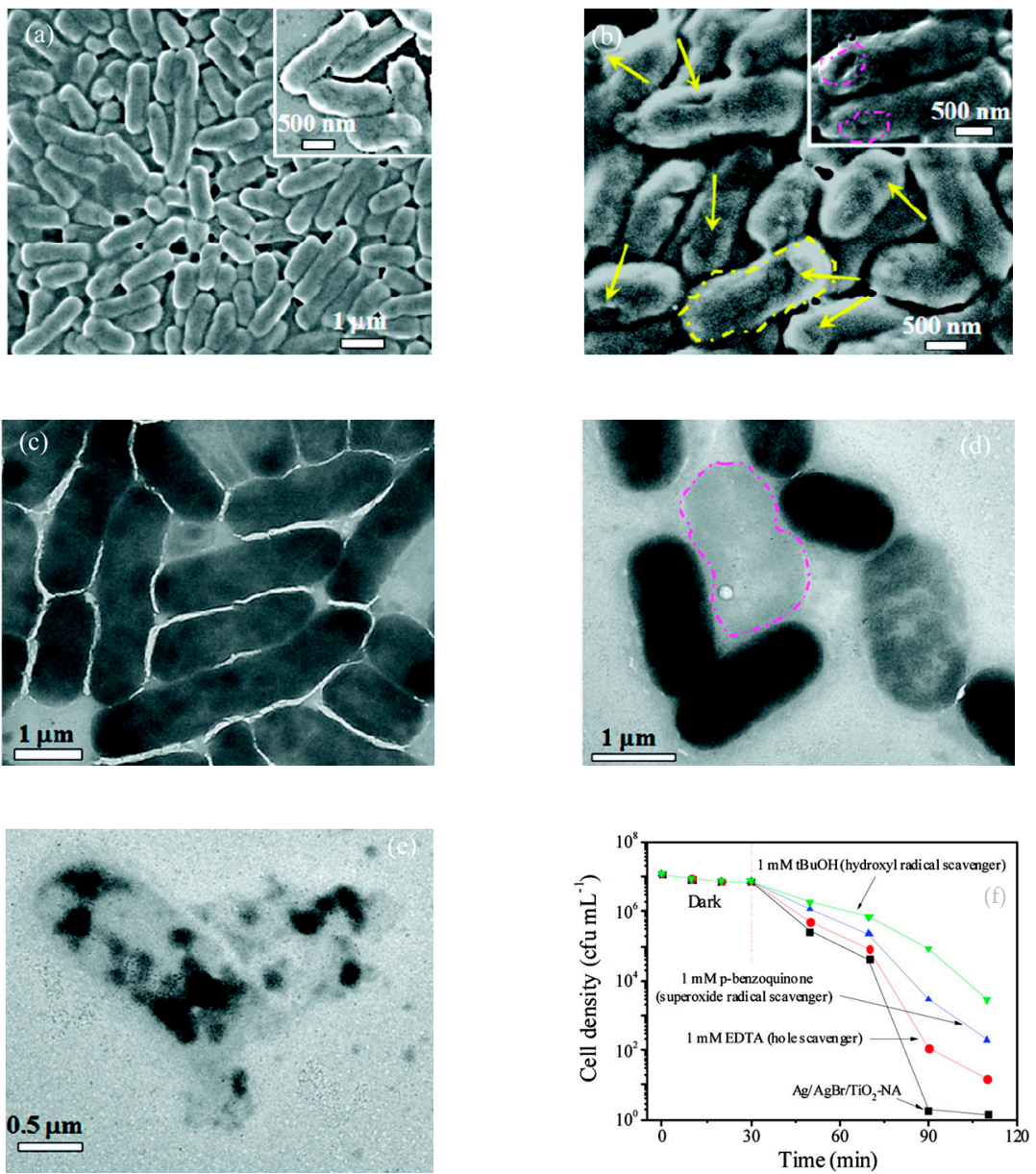

Figure 5. E. coli inactivation by $\mathrm{PEC}$ on $\mathrm{Ag} / \mathrm{AgBr} / \mathrm{TiO}_{2}{ }^{-}$nanotube electrode: (a,b) ESEM images of E. coli: (a) untreated and (b) after PEC inactivation for $80 \mathrm{~min}$; (c,e) TEM images of E. coli: (c) untreated and after PEC inactivation for: (d) $40 \mathrm{~min}$ and (e) $80 \mathrm{~min}$; (f) inhibition of E. coli inactivation by scavengers. Reprinted with permission from [116]. Copyright (2012) American Chemical Society.

Recently, the fungicidal activity of Ag-modified titania has also been studied intensively. Although fungal cells are more complex than bacterial cells and quite resistant to antimicrobial agents, plasmonic photocatalysts have been proposed as effective fungicides [117,124-126]. For example, 
the antifungal activity (C. albicans) of Ag-modified faceted titania (OAP) is much higher than that by OAP modified with other NMNPs $(\mathrm{Cu}, \mathrm{Au}$, and $\mathrm{Pt})$, both under visible light and in the dark (ca. 50\% higher activity under vis during $1 \mathrm{~h}$ ) [117]. Moreover, it has been reported that the fungicidal activity of $\mathrm{Ag}-\mathrm{TiO}_{2}$ depends on the fungal strain and $\mathrm{Ag}$ content [124], and thus the higher content of $\mathrm{Ag}-\mathrm{TiO}_{2}$ or prolonged exposure time might be necessary for specific fungal species [125]. Interestingly, although mono $\mathrm{Ag}$ or $\mathrm{Cu}$-modified titania does not show enhanced activity under visible light, bi-metallic titania $(\mathrm{Ag} / \mathrm{Pt}$ and $\mathrm{Cu} / \mathrm{Ag})$ promote vis activity, due to the oxidation of organic compounds by superoxide anions [126]. Similarly, a synergistic effect has been observed for titania modified with Ag@CuO in respect to mono-modified titania $\left(\mathrm{Ag} / \mathrm{TiO}_{2}\right.$ and $\left.\mathrm{CuO} / \mathrm{TiO}_{2}\right)$ against mold fungi (A. melleus and P. chrysogenum) [127]. Interestingly, only the sample with molar ratio of $\mathrm{Ag}$ to $\mathrm{CuO}$ of 1:3 shows synergism, and only bi-modified samples exhibit higher activity in the dark than that under vis irradiation.

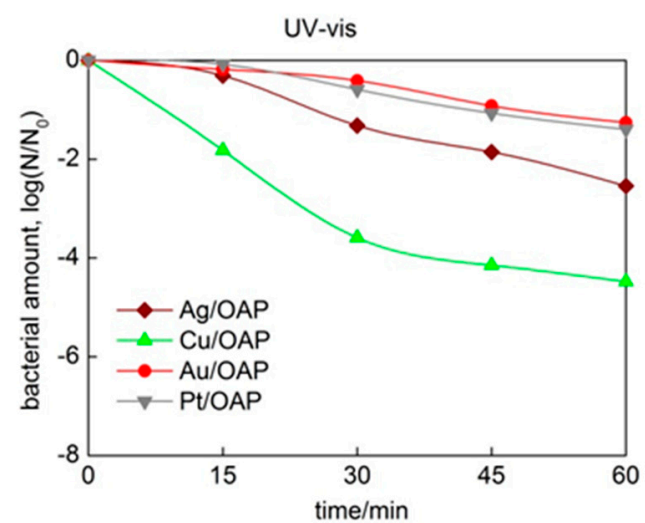

(a)

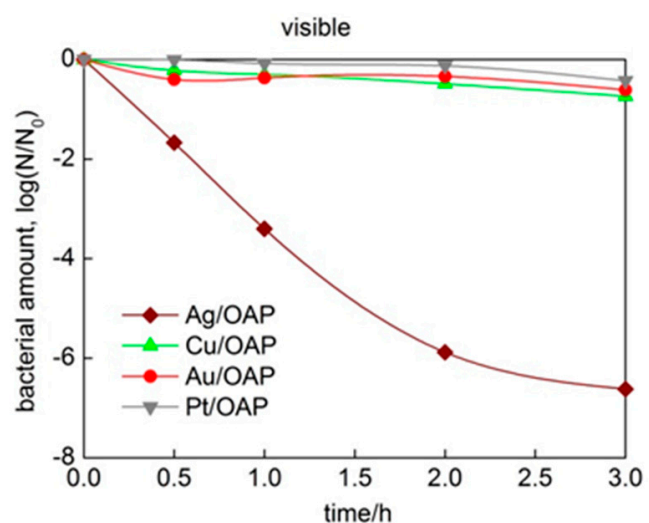

(b)

Figure 6. Antibacterial activity of OAP samples modified with NMNPs under: (a) UV/vis irradiation and (b) vis irradiation; adapted with permission (after formatting) from [117]. Copyright 2017 Creative Commons Attribution.

Table 1. Key-factors of antimicrobial properties of NM-modified titania photocatalysts.

\begin{tabular}{|c|c|c|c|c|c|}
\hline Sample & Preparation Method & Important Properties & Experimental Procedure & Best Performance & Ref. \\
\hline $\mathrm{Ag} / \mathrm{TiO}_{2}$ & hydrothermal synthesis & Ag oxidation & $\begin{array}{l}\text { UV or vis-preirradiated samples } \\
\text { under vis irradiation with } \\
\text { Escherichia coli }\end{array}$ & $\begin{array}{c}\text { non-treated and } \\
\text { vis-preirradiated samples } \\
\text { under vis }\end{array}$ & [109] \\
\hline $\mathrm{Ag} / \mathrm{TiO}_{2}$ & photodeposition & $\mathrm{Ag}$ size & $\begin{array}{l}\text { catalysts suspension with } \\
\text { bacteriophage MS2 under vis, } \\
\text { UV and dark }\end{array}$ & $\begin{array}{l}\text { small } \mathrm{Ag} \text { in dark and large } \mathrm{Ag} \\
\text { under vis }\end{array}$ & [114] \\
\hline $\begin{array}{l}\mathrm{Ag} / \mathrm{OAP} \\
\mathrm{Cu} / \mathrm{OAP}\end{array}$ & $\begin{array}{l}\text { hydrothermal synthesis } \\
\text { (OAP) and Ag or Cu } \\
\text { by photodeposition }\end{array}$ & Ag oxidation, $\mathrm{Ag}$ release & $\begin{array}{l}\text { samples under vis, UV-vis or dark } \\
\text { with E. coli or Candida albicans }\end{array}$ & $\begin{array}{l}\mathrm{Ag} / \mathrm{OAP} \text { under vis for both } \\
\text { E. coli and C. albicans }\end{array}$ & [117] \\
\hline $\begin{array}{l}\mathrm{Ag} / \mathrm{TiO}_{2} \\
\text { (spherical or flower- } \\
\text { like hierarchical) }\end{array}$ & $\begin{array}{c}\text { template induction } \\
\text { (spherical) and } \\
\text { solvothermal (hierarchical) }\end{array}$ & $\begin{array}{l}\text { hierarchical structure, } \\
\text { Ag release, ROS }\end{array}$ & $\begin{array}{l}\text { minimal inhibitory concentration, } \\
\text { growth curves of bacteria and } \\
\text { zone of inhibition against } E \text {. coli } \\
\text { and S. aureus under Xe arc }\end{array}$ & $\begin{array}{l}\text { Ag-modified flower-like } \\
\text { hierarchical titania }\end{array}$ & [118] \\
\hline $\mathrm{Ag} / \mathrm{TiO}_{2}$ & $\begin{array}{l}\text { photochemical reduction } \\
\text { of silver nitrate }\end{array}$ & $\begin{array}{l}\text { Ag size and content, } \\
\text { Ag release }\end{array}$ & $\begin{array}{c}\text { catalysts suspension with } \\
\text { bacteriophage MS2 under UV-A }\end{array}$ & $\begin{array}{l}\text { high content of } \mathrm{Ag} \text { on } \mathrm{TiO}_{2} \\
\text { and small size of } \mathrm{Ag}\end{array}$ & [89] \\
\hline $\mathrm{Cu} / \mathrm{TiO}_{2}$ & impregnation method & $\mathrm{Cu}_{2} \mathrm{O} / \mathrm{CuO}$ ratio & $\begin{array}{c}\text { suspension of E. coli, S. aureus or } \\
\mathrm{Q} \beta \text { bacteriophage on } \mathrm{Cu}_{\mathrm{x}} \mathrm{O} / \mathrm{TiO}_{2} \\
\text { under vis }\end{array}$ & $\begin{array}{l}\mathrm{Cu}_{x} \mathrm{O} \text { clusters; } \mathrm{Cu}_{2} \mathrm{O}: \\
\mathrm{CuO}=1.3: 1 \text { on titania }\end{array}$ & [52] \\
\hline $\begin{array}{l}\mathrm{Ag} @ \mathrm{CuO} \\
/ \mathrm{TiO}_{2}\end{array}$ & $\begin{array}{l}{ }^{60} \text { Co panoramic } \\
\text { gamma irradiation }\end{array}$ & $\mathrm{Ag} / \mathrm{CuO}$ ratio & $\begin{array}{l}\text { colony growth; suspension of } \\
\text { fungal (A. melleus and } \\
\text { P. chrisogenum) spores with } \\
\text { sample under vis }\end{array}$ & $\mathrm{Ag}: \mathrm{CuO}=1: 3$ on titania & [126] \\
\hline $\begin{array}{c}\mathrm{Au} / \mathrm{TiO}_{2} \\
\text { nanotube }\end{array}$ & magnetron sputtering & $\begin{array}{l}\text { size and distribution } \\
\text { of } \mathrm{Au}\end{array}$ & $\begin{array}{l}\text { E. coli or } S \text {. aureus attached on } \\
\qquad \mathrm{Au} / \mathrm{TiO}_{2} \text { in dark }\end{array}$ & $\begin{array}{c}\text { annealed } \mathrm{Au} / \mathrm{TiO}_{2} \text { (large and } \\
\text { isolated Au) }\end{array}$ & [59] \\
\hline $\mathrm{Au} / \mathrm{TiO}_{2}$ & photodeposition & sizes of Au and titania & $\begin{array}{c}\text { inhibition of spore- generation } \\
\text { (A. melleus and P. chrisogenum) } \\
\text { under vis }\end{array}$ & small Au & [115] \\
\hline
\end{tabular}


Copper, especially copper (I) oxide (although it could not be considered as plasmonic, usually a mixed-oxidation state of copper has been reported), has been well known as an antimicrobial agent since ancient times. It has been applied to improve the photo-induced antimicrobial activity of titania. The proposed mechanisms include: (i) the structure of surface proteins being denaturated [94]; (ii) the adsorbed copper ions inducing oxidative stress in the bactericidal processes [95], and the accumulation of copper ions inside bacteria [128]. It has been found that the optimal balance between $\mathrm{Cu}_{2} \mathrm{O}$ and $\mathrm{CuO}$ in the $\mathrm{Cu}_{\mathrm{x}} \mathrm{O} / \mathrm{TiO}_{2}$ composite photocatalyst is important to achieve good antibacterial performance under visible light irradiation and dark conditions, and furthermore that $\mathrm{Cu}_{2} \mathrm{O} / \mathrm{TiO}_{2}$ is more active than $\mathrm{CuO} / \mathrm{TiO}_{2}$ and $\mathrm{CuNPs} / \mathrm{TiO}_{2}$ [52]. The mechanistic study by Rtimi et al. In the presence of scavengers (dimethyl sulfoxide and superoxide dismutase) has shown that the $\mathrm{VB}$ holes in $\mathrm{TiO}_{2}$ and the toxicity of the $\mathrm{Cu}$ ion are responsible for E. coli inactivation under actinic light [111]. In the case of two kinds of faceted anatase photocatalysts (i.e., OAP and DAP (decahedral anatase particle)), the modification with $\mathrm{NM}(\mathrm{Ag}, \mathrm{Cu}, \mathrm{Au}$ and $\mathrm{Pt})$ resulted in enhanced antibacterial activity (in comparison to the activity of bare samples) under vis irradiation $(\lambda>420 \mathrm{~nm})$ against $E$. coli only for Ag- and Cu-modified samples [129]. It has been proposed that the surface oxidation states of NM deposits have been responsible for this behavior (i.e., mainly +1 for $\mathrm{Ag}$ and $\mathrm{Cu}$, and 0 for $\mathrm{Au}$ and $\mathrm{Pt}$ ), resulting in the facile adsorption of $\mathrm{Ag} / \mathrm{Cu}-\mathrm{TiO}_{2}$ on the bacteria surface. Moreover, these results indirectly support the mechanism of plasmonic activation of titania by the charge transfer mechanism, resulting in the formation of more positively charged $\mathrm{Ag} / \mathrm{Cu}$ under vis irradiation, and thus an increase in the overall bactericidal activity $[122,123,129]$. The change in surface oxidation states of NM has been confirmed in another study by XPS analysis for mono- and bi-metal (Au/Ag)-modified titania under monochromatic irradiation $[122,123]$.

In addition to $\mathrm{Ag}$ and $\mathrm{Cu}$, Au-modified titania has also been considered as an antimicrobial agent. Moreover, not only the plasmonic photocatalysis (ROS generation) under irradiation $[61,115,130,131]$, but also electron transfer between Au and bacteria (extracellular electron transfer) [59,132] might cause bacterial death. On the other hand, another report insists that Au-modified titania does not possess any bactericidal property [120]. Although silver-modified samples usually show much higher activity than other plasmonic photocatalysts, gold-modified samples prove to be the most active against mold fungi, especially for the inhibition of the sporulation, as shown in Figure $7[54,115,122]$.

\subsection{Biomedical Applications of Plasmonic Materials}

Considering the use of titania for other biological applications, cancer therapy should be noticed, as already presented for bare titania in Figure $2 b$. Titania has various advantages (e.g., effective ROS generation and non-toxicity), but also disadvantages (e.g., usage of UV light (low penetration through skin, thus, limited to superficial cancer) and no-specification to the target. To overcome these disadvantages, titania has been modified in various ways to obtain visible-near infrared (NIR) response and specification for cancer cells. For example, hydrogenated black titania [133-135], green titania [136], titania modified with NM nanocomposites [137-139], and core/shell photocatalysts with NaYF4: Yb,Tm up-conversion NPs as a core and titania as a shell [140], show NIR absorption and have been proposed for cancer therapy. Among them, plasmonic photocatalysts seem to be the most promising antitumor agents, due to the enhanced photocatalytic property and vis/NIR plasmonic absorption. For example, in the case of Au nanorods and nanoshells, LSPR might be tuned to the NIR region, enabling us to perform in vivo imaging and therapy through the selective localized photothermal heating of cancer cells [141].

$\mathrm{Xu}$ et al. [142] have found that $\mathrm{Au} / \mathrm{TiO}_{2}$ nanocomposites, synthesized by the deposition-precipitation (DP) method, might kill the carcinoma cells efficiently, and the amount of $\mathrm{Au}$ on the surface of $\mathrm{TiO}_{2}$ strongly affects the photocatalytic inactivation efficiency (i.e., $2 \mathrm{wt} \%$ of $\mathrm{Au}$ being the most active). Seo et al. have demonstrated that $\mathrm{Ag} / \mathrm{AgBr} / \mathrm{TiO}_{2} \mathrm{NPs}$ induce the killing of mammalian cancer cell lines in vitro under visible light illumination $(>450 \mathrm{~nm})$ and, moreover, reduced tumor volume in vivo (Figure 8) [139]. 


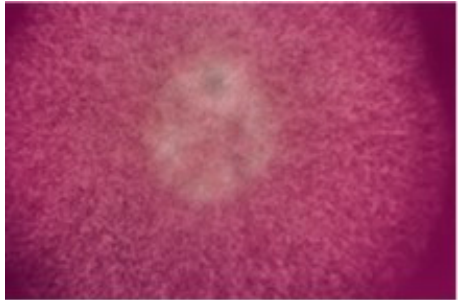

(a)

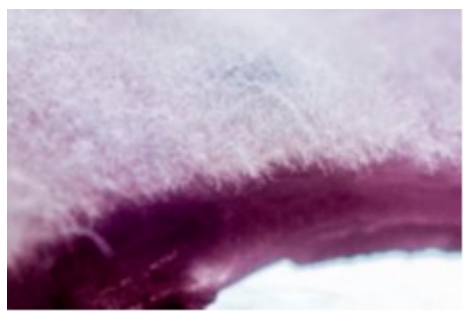

(d)

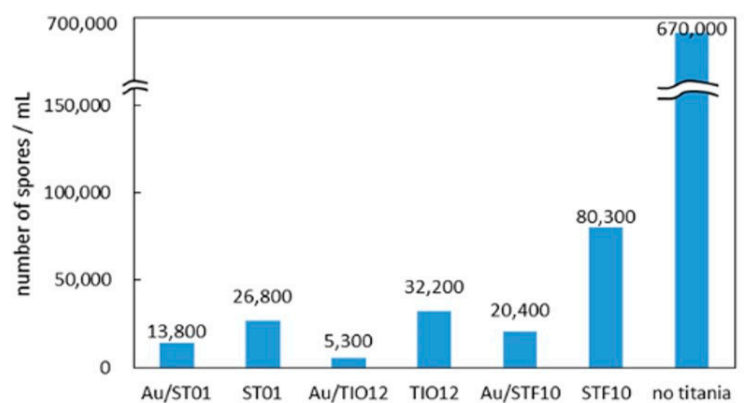

(g)

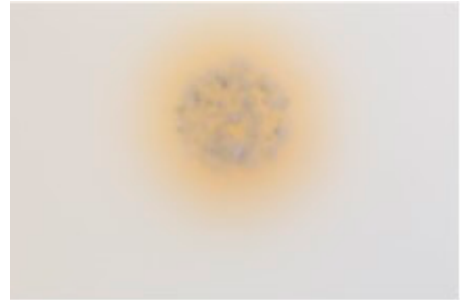

(b)

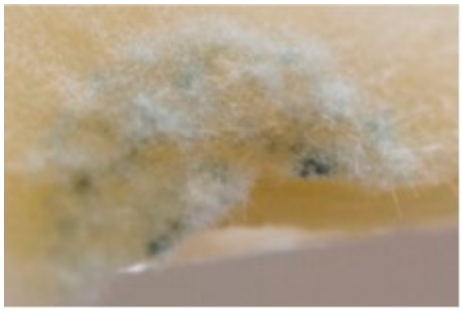

(e)

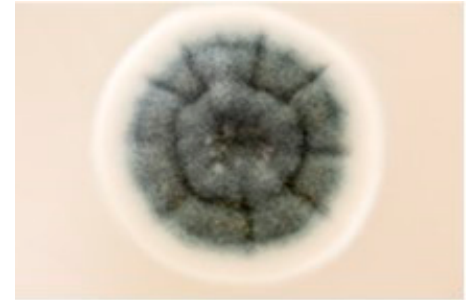

(c)

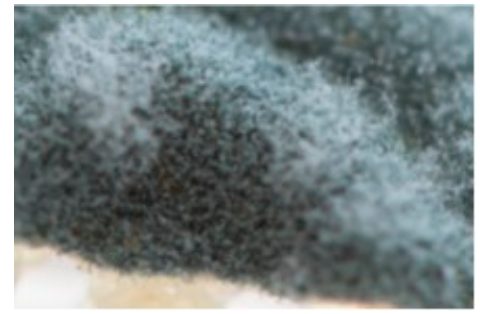

(f)

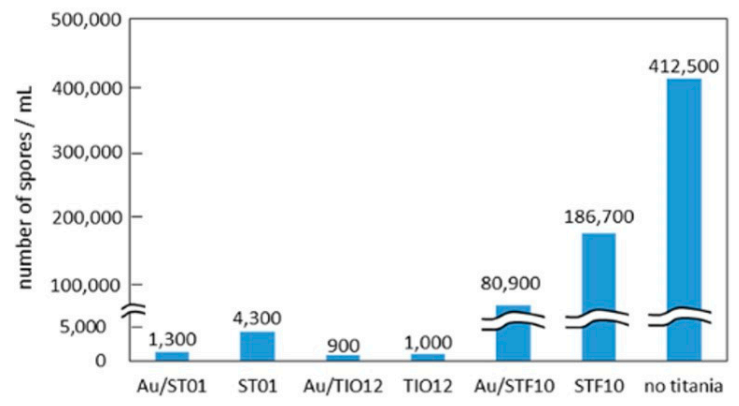

(h)

Figure 7. (a,f) Representative photographs (top view: (a-c), and cross section: (d-f)) of P. chrysogenum cultivated for four days under fluorescent-light irradiation on: (a,d) $\mathrm{Au} / \mathrm{TiO}_{2}$, $(\mathbf{b}, \mathbf{e}) \mathrm{TiO}_{2}$, (c,f) without photocatalyst. (g,h) Number of spores after five days of growth under vis irradiation for: (g) P. chrysogenum and (h) A. melleus; ST01, TIO12 and STF10-different samples of commercial titania—and Au/ST01, Au/TIO12 and AU/STF10 — respective titania modified with gold NPs; adapted with permission from [115]. Copyright 2018, Creative Commons Attribution.
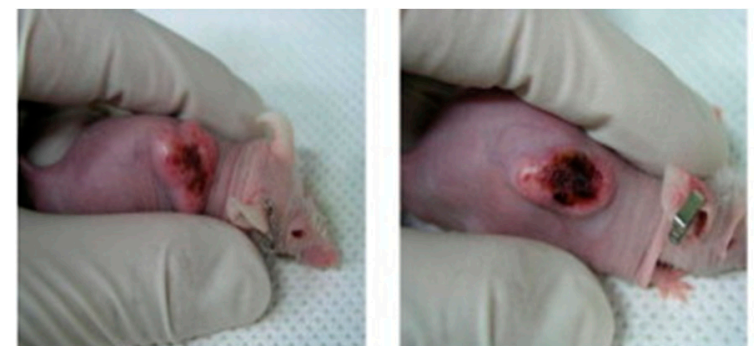

(a)
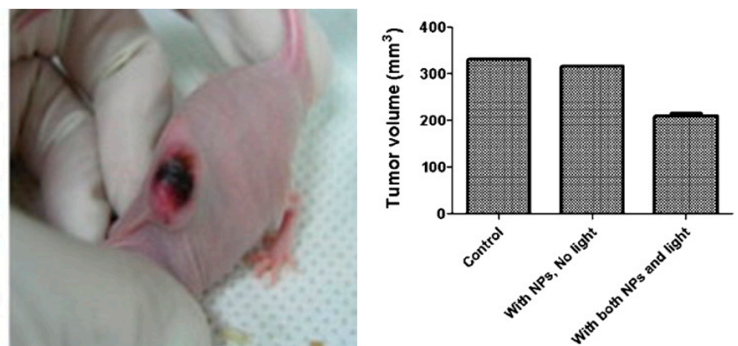

(b)

Figure 8. (a) Photographs of A431-heterograft tumor on mice in the absence of $\mathrm{Ag} / \mathrm{AgBr} / \mathrm{TiO} \mathrm{NPs}_{2}$ and irradiation for $10 \mathrm{~min}$ (left), in the presence of NPs without irradiation (middle), and in the presence of both NPs and irradiation for $10 \mathrm{~min}$ (right); (b) The measured tumor volumes $\left(\mathrm{mm}^{3}\right)$ for the three types of samples. Reprinted with permission (after formatting) from [139]. Copyright (2011) Elsevier.

Although plasmonic photocatalysts might cause an anticancer effect, they are deficient in the specificity. Therefore, similar to drug delivery systems, titania has been modified with various 
components. For example, some receptors are overexpressed on the surface of cancer cells (e.g., epidermal growth factor receptor (EGFR) [143], interleukin-13R2 receptor domain (IL13R2R) [144] and folic acid-folate receptor [145]). Accordingly, in order to add the binding ability to cancer cells to titania (or other materials), an 11 amino acid peptide fragment of EGF [143], anti-IL13R2R antibody [144], and folic acid [145] are first conjugated with titania. Accordingly, the bound titania to receptor is uptaken by endocytosis, incorporating into cytoplasm, and then probably into nucleus. Next, ROS are generated under irradiation and attack proteins, lipids, nucleic acid, and so on, inducing cell death by apoptosis or necrosis. Recently, it has been found that nuclear-targeted AuNPs (AuNPs with three ligands, methoxypolyethylene glycol thiol (PEG), RGD (RGDRGDRGDRGDPGC) peptides, and nuclear localization signal (NLS, CGGGPKKKRKVGG) peptides), inhibit cancer cell migration by increasing their nuclear stiffness, which greatly reduces the AuNP dosage, resulting in the suppression of the metastasis [146]. Moreover, Ali et al. have proposed that integrin-targeted Au nanorods (Au nanorods with Arg-Gly-Asp (RGD) peptide), activated by NIR light, causes changes in cell morphology and a decrease in cell migration [138], since integrin plays critical roles in controlling the organization of cytoskeletons (strongly related to cell migration).

On the other hand, plasmonic photocatalysts might be used as drug-delivery carriers for anti-tumor drugs [137]. For example, gold nanorods (GNR)/ $/ \mathrm{TiO}_{2}$ has been used as the carrier of gambogic acid (GA), a potent anticancer agent with poor solubility in aqueous solutions, providing the stable dispersion and enhanced intracellular GA delivery. Moreover, $\mathrm{GNR} / \mathrm{TiO}_{2}$ shows high photothermal conversion efficiency, and thus irradiation with low-intense laser at $808 \mathrm{~nm}$ has enhanced the anticancer effect of the GA-loaded GNR/ $\mathrm{TiO}_{2}$, resulting in the improvement of the therapeutic efficacy of GA (Figure 9).

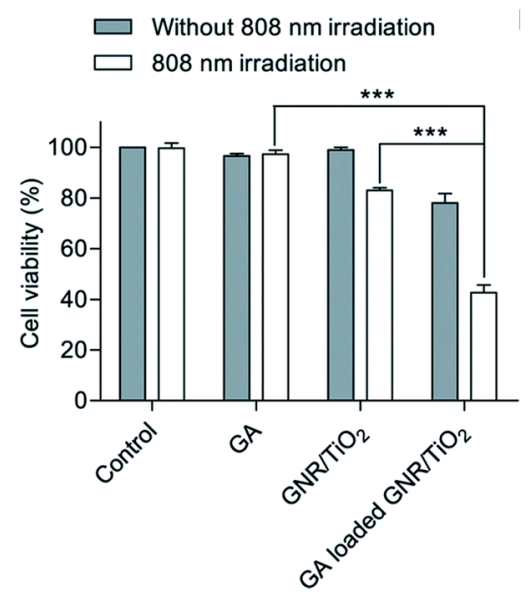

(a)

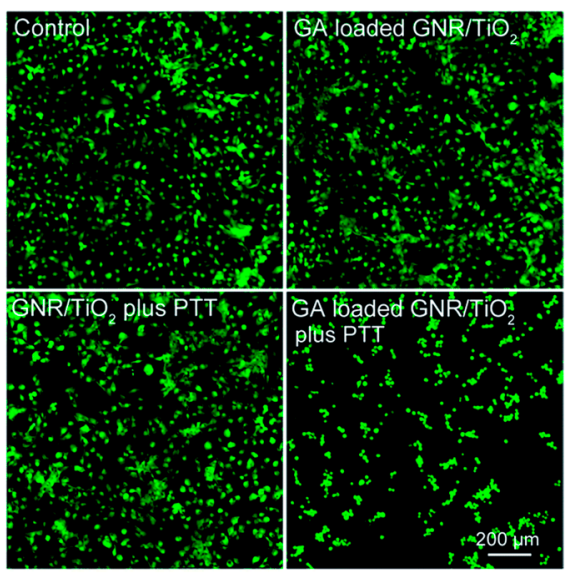

(b)

Figure 9. Enhanced cytotoxic effect of GA by using GNR/TiO2 nanostructure-mediated photothermal therapy. U-87 MG cells were incubated with GNR/TiO2 or GA-loaded GNR/TiO2 nanostructures for $24 \mathrm{~h}$, followed by $808 \mathrm{~nm}$ NIR irradiation $\left(5.3 \mathrm{~W} \mathrm{~cm}^{-2}\right)$ for $2 \mathrm{~min}$. After incubation for $24 \mathrm{~h}$, cell viability was determined using an ATP assay (a) and calcein AM staining; (b) Live cells were stained with green fluorescence by calcein AM. The data shown represent the mean \pm S.E.M., ${ }^{* * *} p<0.001$. Reprinted with permission (after formatting) from [137]. Copyright (2017) The Royal Society of Chemistry.

\section{Conclusions}

Plasmonic photocatalysts have proved to be efficient agents against various microorganisms. Their activity is usually much higher under vis irradiation than in the dark (intrinsic properties of noble metals), resulting from the generation of ROS and the direct redox reactions between microorganisms and photocatalysts. The properties of both photocatalysts and target microorganisms are crucial for the overall antimicrobial effect. Generally, smaller NPs (and thus larger specific surface area) and more simple organisms have shown fast and efficient microbial inactivation. 
Unfortunately, some contradictory results have been published. It might be expected that some experiments have been performed in the presence of UV irradiation (e.g., indoor light, artificial or natural solar light), and thus different mechanisms of microorganism inactivation should be considered, i.e., direct excitation of wide-bandgap semiconductor (under UV) and plasmonic excitation (under vis). Considering "hot" electron transfer under plasmonic excitation, the opposite electron transfer under vis and UV is expected, i.e., from NM to semiconductor and from semiconductor to NM, respectively. Therefore, the change in the oxidation state of less noble metals (e.g., $\mathrm{Ag}$ and $\mathrm{Cu}$ ) might result in the facile adsorption of the photocatalyst on the surface of microorganisms, but also a release of metal cations into solution/suspension. For the mechanisms study, it seems that the tests under sole vis (also under sole UV for the comparison) and in the dark are the most recommended (e.g., by action spectra analysis).

The other microbiological applications of plasmonic photocatalysts are also quite promising, especially for cancer treatment and anticancer therapy, but more studies on the improved selectivity against only danger cells are highly necessary.

Author Contributions: Conceptualization, E.K.; writing—original draft preparation, M.E.-K.; writing—review and editing, E.K. and M.E.-K.; supervision, E.K. All authors have read and agreed to the published version of the manuscript.

Funding: This research was funded by a Grand Challenges Explorations Grant (GCE RB, OPP1060234) from Bill \& Melinda Gates Foundation, and "Yugo-Sohatsu Kenkyu" for an Integrated Research Consortium on Chemical Sciences (IRCCS) project from the Ministry of Education and Culture, Sport, Science and Technology-Japan (MEXT). The APC was funded by E.K.

Acknowledgments: Authors thank Agata Markowska-Szczupak from Western Pomeranian University of Technology in Szczecin, for fruitful discussion, motivation, and support.

Conflicts of Interest: The authors declare no conflict of interest.

\section{References}

1. United Nations. Sustainable Development Goals; 6. Clean Water and Sanitation, (n.d.). Available online: https://www.un.org/sustainabledevelopment/water-and-sanitation/ (accessed on 1 March 2020).

2. WHO. Guidelines for Drinking-Water Quality, 4th ed.; WHO: Geneva, Switzerland, 2011.

3. Thomas, V.G.; Guitart, R. Limitations of European Union policy and law for regulating use of lead shot and sinkers: Comparisons with North American regulation. Environ. Policy Gov. 2010, 20, 57-72. [CrossRef]

4. Van Grinsven, H.J.M.; Ten Berge, H.F.M.; Dalgaard, T.; Fraters, B.; Durand, P.; Hart, A.; Hofman, G.; Jacobsen, B.H.; Lalor, S.T.J.; Lesschen, J.P.; et al. Management, regulation and environmental impacts of nitrogen fertilization in northwesternEurope under the Nitrates Directive; A benchmark study. Biogeosciences 2012, 9, 5143-5160. [CrossRef]

5. Beulke, S.; van Beinum, W.; Suddaby, L. Interpretation of aged sorption studies for pesticides and their use. In European Union regulatory leaching assessments. Integr. Environ. Assess. Manag. 2015, 11, 276-286. [CrossRef] [PubMed]

6. Pichat, P. A Brief Survey of the Potential Health Risks of $\mathrm{TiO}_{2}$. J. Adv. Oxid. Technol. 2010, 13, 238-246.

7. Arslan, I.; Balcioglu, I.A.; Tuhkanen, T. Advanced Oxidation of Synthetic Dyehouse Effluent by $\mathrm{O}_{3}, \mathrm{H}_{2} \mathrm{O}_{2} / \mathrm{O}_{3}$ and $\mathrm{H}_{2} \mathrm{O}_{2} / \mathrm{UV}$ Processes. Environ. Technol. 1999, 20, 921-931. [CrossRef]

8. Kowalska, E.; Janczarek, M.; Hupka, J.; Grynkiewicz, M. $\mathrm{H}_{2} \mathrm{O}_{2} / \mathrm{UV}$ enhanced degradation of pesticides in wastewater. Water Sci. Technol. 2004, 49, 261-266. [CrossRef]

9. Barbeni, M.; Minero, C.; Pelizzetti, E.; Borgarello, E.; Serpone, N. Chemical degradation of chlorophenols with Fenton's reagent $\left(\mathrm{Fe}^{2+}+\mathrm{H}_{2} \mathrm{O}_{2}\right)$. Chemosphere 1987, 16, 2225-2237. [CrossRef]

10. Karci, A.; Arslan-Alaton, I.; Olmez-Hanci, T.; Bekbolet, M. Transformation of 2,4-dichlorophenol by $\mathrm{H}_{2} \mathrm{O}_{2} / \mathrm{UV}-\mathrm{C}$, Fenton and photo-Fenton processes: Oxidation products and toxicity evolution. J. Photochem. Photobiol. A Chem. 2012, 230, 65-73. [CrossRef]

11. Mozia, S.; Tomaszewska, M.; Morawski, A.W. Application of an ozonation-adsorption-ultrafiltration system for surface water treatment. Desalination 2006, 190, 308-314. [CrossRef] 
12. King, C.H.; Shotts, E.B.; Wooley, R.E.; Porter, K.G. Survival of coliforms and bacterial pathogens within protozoa during chlorination. Appl. Environ. Microbiol. 1988, 54, 3023-3033. [CrossRef]

13. Mokrini, A.; Ousse, D.; Esplugas, S. Oxidation of aromatic compounds with UV radiation/ozoneihydrogen peroxide. Water Sci. Technol. 1997, 35, 95-102. [CrossRef]

14. Tomova, D.; Iliev, V.; Rakovsky, S.; Anachkov, M.; Eliyas, A.; Puma, G.L. Photocatalytic oxidation of 2,4,6 trinitrotoluene in the presence of ozone under irradiation with UV and visible light. J. Photochem. Photobiol. A Chem. 2012, 231, 1-8. [CrossRef]

15. Hoffmann, M.R.; Martin, S.T.; Choi, W.; Bahnemann, D.W. Environmental applications of photocatalysis. Chem. Rev. 1995, 95, 69-96. [CrossRef]

16. Bahnemann, D.W.; Cunningham, J.; Al-Sayyed, G.; Srijaranai, S. Photocatalytic treatment of waters. In Aquatic and Surface Photochemistry; Lewis Publ.: Boca Raton, FL, USA, 1994; pp. 261-314.

17. Duffy, J.E.; Anderson, M.A.; Hill, C.G.; Zeltner, W.A. Photocatalytic oxidation as a secondary treatment method following wet air oxidation. Ind. Eng. Chem. Res. 2000, 39, 3698-3706. [CrossRef]

18. Sánchez-Oneto, J.; Mancini, F.; Portela, J.R.; Nebot, E.; Cansell, F.; Martínez de la Ossa, E.J. Kinetic model for oxygen concentration dependence in the supercritical water oxidation of an industrial wastewater. Chem. Eng. J. 2008, 144, 361-367. [CrossRef]

19. Legrini, O.; Oliveros, E.; Braun, A.M. Photochemical processes for water treatment. Chem. Rev 1993, 93, 671-698. [CrossRef]

20. Sun, L.; Bolton, J.R. Determination of the quantum yield for the photochemical generation of hydroxyl adicals in $\mathrm{TiO}_{2}$ suspensions. J. Phys. Chem. 1996, 100, 4127-4134. [CrossRef]

21. Pelaez, M.; Nolan, N.T.; Pillai, S.C.; Seery, M.K.; Falaras, P.; Kontos, A.G.; Dunlop, P.S.M.; Hamilton, J.W.J.; Byrne, J.A.; O'Shea, K.; et al. A review on the visible light active titanium dioxide photocatalysts for environmental applications. Appl. Catal. B Environ. 2012, 125, 331-349. [CrossRef]

22. Zaleska, A. Doped-TiO 2 : A review. Recent Pat. Eng. 2008, 2, 157-164. [CrossRef]

23. Asahi, R.; Morikawa, T.; Ohwaki, T.; Aoki, K.; Taga, Y. Visible-light photocatalysis in nitrogen-doped. titanium oxides. Science 2011, 293, 269-271. [CrossRef]

24. Mitoraj, D.; Jańczyk, A.; Strus, M.; Kisch, H.; Stochel, G.; Heczko, P.B.; Macyk, W. Visible light inactivation of bacteria and fungi by modified titanium dioxide. Photochem. Photobiol. Sci. 2007, 6, 642-648. [CrossRef] [PubMed]

25. Sakthivel, S.; Janczarek, M.; Kisch, H. Visible light activity and photoelectrochemical properties of nitrogen-doped $\mathrm{TiO}_{2}$. J. Phys. Chem. B 2004, 108, 19384-19387. [CrossRef]

26. Bledowski, M.; Wang, L.; Ramakrishnan, A.; Khavryuchenko, O.V.; Khavryuchenko, V.D.; Ricci, P.C.; Strunk, J.; Cremer, T.; Kolbeck, C.; Beranek, R. Visible-light photocurrent response of $\mathrm{TiO}_{2}$-polyheptazine hybrids: Evidence for interfacial charge-transfer absorption. Phys. Chem. Chem. Phys. 2011, 13, 21511-21519. [CrossRef] [PubMed]

27. Dozzi, M.V.; Selli, E. Doping $\mathrm{TiO}_{2}$ with p-block elements: Effects on photocatalytic activity. J. Photochem. Photobiol. C Photochem. Rev. 2013, 14, 13-28. [CrossRef]

28. Georgieva, J.; Sotiropoulos, S.; Armyanov, S.; Philippidis, N.; Poulios, I. Photoelectrocatalytic activity of bi-layer $\mathrm{TiO}_{2} / \mathrm{WO}_{3}$ coatings for the degradation of 4-chlorophenol: Effect of morphology and catalyst loading. J. Appl. Electrochem. 2011, 41, 173-181. [CrossRef]

29. Li, G.; Nie, X.; Gao, Y.; An, T. Can environmental pharmaceuticals be photocatalytically degraded and completely mineralized in water using $\mathrm{g}-\mathrm{C}_{3} \mathrm{~N}_{4} / \mathrm{TiO}_{2}$ under visible light irradiation? -Implications of persistent toxic intermediates. Appl. Catal. B Environ. 2016, 180, 726-732. [CrossRef]

30. Serpone, N.; Maruthamuthu, P.; Pichat, P.; Pelizzetti, E.; Hidaka, H. Exploiting the interparticle electron transfer process in the photocatalysed oxidation of phenol, 2-chlorophenol and pentachlorophenol: Chemical evidence for electron and hole transfer between coupled semiconductors. J. Photochem. Photobiol. A Chem. 1995, 85, 247-255. [CrossRef]

31. Kraeutler, B.; Bard, A.J. Heterogeneous photocatalytic preparation of supported catalysts. Photodeposition of platinum on $\mathrm{TiO}_{2}$ powder and other substrates. J. Am. Chem. Soc. 1978, 100, 4317-4318. [CrossRef]

32. Kowalska, E.; Remita, H.; Colbeau-Justin, C.; Hupka, J.; Belloni, J. Modification of titanium dioxide with platinum ions and clusters: Application in photocatalysis. J. Phys. Chem. C. 2008, 112, 1124-1131. [CrossRef] 
33. Kowalska, E.; Yoshiiri, K.; Wei, Z.; Zheng, S.; Kastl, E.; Remita, H.; Ohtani, B.; Rau, S. Hybrid photocatalysts composed of titania modified with plasmonic nanoparticles and ruthenium complexes for decomposition of organic compounds. Appl. Catal. B Environ. 2015, 178, 133-143. [CrossRef]

34. Sze, S.M.; Ng, K.K. Physics of Semiconductor Devices, 3rd ed.; John Wiley \& Sons: Hoboken, NJ, USA, 2007.

35. Tian, Y.; Notsu, H.; Tatsuma, T. Visible-light-induced patterning of Au- and $\mathrm{Ag}-\mathrm{TiO}_{2}$ nanocomposite film surfaces on the basis of plasmon photoelectrochemistry. Photochem. Photobiol. Sci. 2005, 4, 598-601. [CrossRef] [PubMed]

36. Verbruggen, S.W.; Keulemans, M.; Goris, B.; Blommaerts, N.; Bals, S.; Martens, J.A.; Lenaerts, S. Plasmonic "rainbow" photocatalyst with broadband solar light response for environmental applications. Appl. Catal. B Environ. 2016, 188, 147-153. [CrossRef]

37. Jain, P.K.; Lee, K.S.; El-Sayed, I.H.; El-Sayed, M.A. Calculated absorption and scattering properties of gold nanoparticles of different size, shape, and composition: Applications in biological imaging and biomedicine. J. Phys. Chem. B 2016, 110, 7238-7248. [CrossRef]

38. Kowalska, E.; Abe, R.; Ohtani, B. Visible light-induced photocatalytic reaction of gold-modified titanium(IV) oxide particles: Action spectrum analysis. Chem. Commun. 2009, 14, 241-243. [CrossRef] [PubMed]

39. Kowalska, E.; Prieto-Mahaney, O.O.; Abe, R.; Ohtani, B. Visible-light-induced photocatalysis through surface plasmon excitation of gold on titania surfaces. Phys. Chem. Chem. Phys. 2010, 12, 2344-2355. [CrossRef]

40. Sakai, N.; Fujiwara, Y.; Takahashi, Y.; Tatsuma, T. Plasmon-resonance-based generation of cathodic photocurrent at electrodeposited gold nanoparticles coated with $\mathrm{TiO}_{2}$ films. ChemPhysChem 2009, 10, 766-769. [CrossRef]

41. Sakai, N.; Fujiwara, Y.; Arai, M.; Yu, K.; Tatsuma, T. Electrodeposition of gold nanoparticles on ITO: Control of morphology and plasmon resonance-based absorption and scattering. J. Electroanal. Chem. 2009, 628, 7-15. [CrossRef]

42. Cushing, S.K.; Li, J.; Meng, F.; Senty, T.R.; Suri, S.; Zhi, M.; Li, M.; Bristow, A.D.; Wu, N. Photocatalytic activity enhanced by plasmonic resonant energy transfer from metal to semiconductor. J. Am. Chem. Soc. 2012, 134, 15033-15041. [CrossRef]

43. Bouhadoun, S.; Guillard, C.; Dapozze, F.; Singh, S.; Amans, D.; Bouclé, J.; Herlin-Boime, N. One step synthesis of $\mathrm{N}$-doped and $\mathrm{Au}$-loaded $\mathrm{TiO}_{2}$ nanoparticles by laser pyrolysis: Application in photocatalysis. Appl. Catal. B Environ. 2015, 174, 367-375. [CrossRef]

44. Choi, Y.; Kang, T.; Lee, L.P. Plasmon resonance energy transfer (PRET)-based molecular imaging of cytochrome $\mathrm{C}$ in living cells. Nano Lett. 2009, 9, 85-90. [CrossRef]

45. Chen, X.; Zhu, H.Y.; Zhao, J.C.; Zheng, Z.F.; Gao, X.P. Visible-light-driven oxidation of organic contaminants in air with gold nanoparticle catalysts on oxide supports. Angew. Chem. 2008, 47, 5353-5356. [CrossRef] [PubMed]

46. Bora, T.; Zoepfl, D.; Dutta, J. Importance of plasmonic heating on visible light driven photocatalysis of gold nanoparticle decorated zinc oxide nanorods. Sci. Rep. 2016, 6, 1-10. [CrossRef] [PubMed]

47. Golubev, A.A.; Khlebtsov, B.N.; Rodriguez, R.D.; Chen, Y.; Zahn, D.R.T. Plasmonic heating plays a dominant role in the plasmon-induced photocatalytic reduction of 4-nitrobenzenethiol. J. Phys. Chem. C 2018, 122, 5657-5663. [CrossRef]

48. Wang, C.; Ranasingha, O.; Natesakhawat, S.; Ohodnicki, P.R.; Andio, M.; Lewis, J.P.; Matranga, C. Visible light plasmonic heating of $\mathrm{Au}-\mathrm{ZnO}$ for the catalytic reduction of $\mathrm{CO}_{2}$. Nanoscale 2013, 5, 6968-6974. [CrossRef] [PubMed]

49. Wei, Z.; Janczarek, M.; Endo, M.; Balcytis, A.; Nitta, A.; Mendez Medrano, M.G.; Colbeau-Justin, C.; Juodkazis, S.; Ohtani, B.; Kowalska, E. Noble metal-modified facetted anatase titania photocatalysts: Octahedron versus decahedron. Appl. Catal. B Environ. 2018, 237, 574-587. [CrossRef]

50. Kowalska, E.; Rau, S.; Ohtani, B. Plasmonic titania photocatalysts active under UV and visible-light irradiation: Influence of gold amount, size, and shape. J. Nanotechnol. 2012. [CrossRef]

51. Huang, L.; Peng, F.; Wang, H.; Yu, H.; Li, Z. Preparation and characterization of $\mathrm{Cu}_{2} \mathrm{O} / \mathrm{TiO}_{2}$ nano-nano heterostructure photocatalysts. Catal. Commun. 2009, 10, 1839-1843. [CrossRef]

52. Qiu, X.; Miyauchi, M.; Sunada, K.; Minoshima, M.; Liu, M.; Lu, Y.; Li, D.; Shimodaira, Y.; Hosogi, Y.; Kuroda, Y.; et al. Hybrid $\mathrm{Cu}_{\mathrm{x}} \mathrm{O} / \mathrm{TiO}_{2}$ nanocomposites as risk-reduction materials in indoor environments. ACS Nano. 2012, 6, 1609-1618. [CrossRef] 
53. Zielińska-Jurek, A.; Kowalska, E.; Sobczak, J.W.; Lisowski, W.; Ohtani, B.; Zaleska, A. Preparation and characterization of monometallic $(\mathrm{Au})$ and bimetallic $(\mathrm{Ag} / \mathrm{Au})$ modified-titania photocatalysts activated by visible light. Appl. Catal. B Environ. 2011, 101, 504-514. [CrossRef]

54. Kowalska, E.; Wei, Z.S.; Karabiyik, B.; Janczarek, M.; Endo, M.; Wang, K.L.; Rokicka, P.; Markowska-Szczupak, A.; Ohtani, B. Development of plasmonic photocatalysts for environmental application. Adv. Sci. Technol. 2014, 93, 174-183. [CrossRef]

55. Méndez-Medrano, M.G.; Kowalska, E.; Lehoux, A.; Herissan, A.; Ohtani, B.; Bahena, D.; Briois, V.; Colbeau-Justin, C.; Rodríguez-López, J.L.; Remita, H. Surface modification of $\mathrm{TiO}_{2}$ with $\mathrm{Ag}$ nanoparticles and $\mathrm{CuO}$ nanoclusters for application in photocatalysis. J. Phys. Chem. C 2016, 120, 5143-5154. [CrossRef]

56. Mo, A.; Liao, J.; Xu, W.; Xian, S.; Li, Y.; Bai, S. Preparation and antibacterial effect of silver-hydroxyapatite/ titania nanocomposite thin film on titanium. Appl. Surf. Sci. 2008, 255, 435-438. [CrossRef]

57. Padervand, M.; Reza Elahifard, M.; Vatan Meidanshahi, R.; Ghasemi, S.; Haghighi, S.; Reza Gholami, M. nvestigation of the antibacterial and photocatalytic properties of the zeolitic nanosized $\mathrm{AgBr} / \mathrm{TiO} 2$ composites. Mater. Sci. Semicond. Process. 2012, 15, 73-79. [CrossRef]

58. Jansson, I.; Yoshiiri, K.; Hori, H.; Garcia-Garcia, F.J.; Rojas, S.; Sanchez, B.; Ohtani, B.; Suerez, S. Cerebral aneurysm surgery based on preoperative computerized tomography angiography. J. Neurosurg. 2016, 521, 208-219.

59. Li, J.; Zhou, H.; Qian, S.; Liu, Z.; Feng, J.; Jin, P.; Liu, X. Plasmonic gold nanoparticles modified titania nanotubes for antibacterial application. Appl. Phys. Lett. 2014, 104, 261110. [CrossRef]

60. Bian, Z.; Tachikawa, T.; Zhang, P.; Fujitsuka, M.; Majima, T. Au/ $\mathrm{TiO}_{2}$ superstructure-based plasmonic photocatalysts exhibiting efficient charge separation and unprecedented activity. J. Am. Chem. Soc. 2014, 136, 458-465. [CrossRef]

61. Guo, L.; Shan, C.; Liang, J.; Ni, J.; Tong, M. Bactericidal mechanisms of Au@TNBs under visible light irradiation. Colloids Surf. B Biointerfaces 2015, 128, 211-218. [CrossRef]

62. Matsunaga, T.; Tomoda, R.; Nakajima, T.; Wake, H. Photoelectrochemical sterilization of microbial cells by semiconductor powders. FEMS Microbiol. Lett. 1985, 29, 211-214. [CrossRef]

63. Matsunaga, T.; Tomoda, R.; Nakajima, T.; Nakamura, N.; Komine, T. Continuous-sterilization system that uses photosemiconductor powders. Appl. Environ. Microbiol. 1988, 54, 1330-1333. [CrossRef]

64. Huang, Z.; Maness, P.-C.; Blake, D.M.; Wolfrum, E.J.; Smolinski, S.L.; Jacoby, W.A. Bactericidal mode of titanium dioxide photocatalysis. J. Photochem. Photobiol. A Chem. 2000, 130, 163-170. [CrossRef]

65. Markowska-Szczupak, A.; Ulfig, K.; Morawski, A.W. The application of titanium dioxide for deactivation of bioparticulates: An overview. Catal. Today 2011, 169, 249-257. [CrossRef]

66. Kiwi, J.; Nadtochenko, V. New evidence for $\mathrm{TiO}_{2}$ photocatalysis during bilayer lipid peroxidation. J. Phys. Chem. B. 2004, 108, 17675-17684. [CrossRef]

67. Kiwi, J.; Nadtochenko, V. Evidence for the mechanism of photocatalytic degradation of the bacterial wall membrane at the $\mathrm{TiO}_{2}$ interface by ATR-FTIR and laser kinetic spectroscopy. Langmuir 2005, 21, 4631-4641. [CrossRef] [PubMed]

68. Cho, M.; Chung, H.; Choi, W.; Yoon, J. Linear correlation between inactivation of E. coli and OH radical concentration in $\mathrm{TiO}_{2}$ photocatalytic disinfection. Water Res. 2004, 38, 1069-1077. [CrossRef]

69. Wang, X.; Tang, Y.; Chen, Z.; Lim, T.T. Highly stable heterostructured Ag-AgBr/TiO 2 composite: A bifunctional visible-light active photocatalyst for destruction of ibuprofen and bacteria. J. Mater. Chem. 2012, 22, 23149-23158. [CrossRef]

70. Du, J.; Gebicki, J.M. Proteins are major initial cell targets of hydroxyl free radicals. Int. J. Biochem. Cell Biol. 2004, 36, 2334-2343. [CrossRef]

71. Battistoni, A. Role of prokaryotic $\mathrm{Cu}, \mathrm{Zn}$ superoxide dismutase in pathogenesis. Biochem. Soc. Trans. 2003, 31, 1326-1329. [CrossRef]

72. Wintjens, R.; Noël, C.; May, A.C.; Gerbod, D.; Dufernez, F.; Capron, M.; Viscogliosi, E.; Rooman, M. Specificity and Phenetic Relationships of Iron- and Manganese-containing Superoxide Dismutases on the Basis of Structure and Sequence Comparisons. J. Biol. Chem. 2004, 279, 9248-9254. [CrossRef]

73. Harris, A.G.; Hinds, F.E.; Beckhouse, A.G.; Kolesnikow, T.; Hazell, S.L. Resistance to hydrogen peroxide in Helicobacter pylori: Role of catalase (KatA) and Fur, and functional analysis of a novel gene product designated "KatA-associated protein", KapA (HP0874). Microbiology 2002, 148, 3813-3825. [CrossRef] 
74. Harris, A.G.; Hazell, S.L. Localisation of Helicobacter pylori catalase in both the periplasm and cytoplasm, and its dependence on the twin-arginine target protein, KapA, for activity. FEMS Microbiol. Lett. 2003, 229, 283-289. [CrossRef]

75. Markowska-Szczupak, A.; Rokicka, P.; Wang, K.; Endo, M.; Morawski, A.W.; Kowalska, E. Photocatalytic water disinfection under solar radiation by D-glucose modified titania. Catalysts 2018, 8, 316. [CrossRef]

76. Jakob, U.; Muse, W.; Eser, M.; Bardwell, J.C.A. Chaperone activity with a redox switch. Cell 1999, 96, 341-352. [CrossRef]

77. Volkert, M.R.; Landini, P. Transcriptional responses to DNA damage. Curr. Opin. Microbiol. 2001, 4, $178-185$. [CrossRef]

78. Chaffin, W.L.; López-Ribot, J.L.; Casanova, M.; Gozalbo, D.; Martínez, J.P. Cell wall and secreted proteins of Candida albicans: Identification, Function, and Expression. Microbiol. Mol. Biol. Rev. 1998, 62, 130-180. [CrossRef] [PubMed]

79. Markowska-Szczupak, A.; Wang, K.; Rokicka, P.; Endo, M.; Wei, Z.; Ohtani, B.; Morawski, A.W.; Kowalska, E. The effect of anatase and rutile isolated from titania P25 on pathogenic fungi. J. Photochem. Photobiol. B 2015, 151, 54-62. [CrossRef] [PubMed]

80. Markowska-Szczupak, A.; Wei, Z.; Kowalska, E. The influence of the light-activated titania P25 on human breast cancer cells. Catalysts 2020, 10, 238. [CrossRef]

81. Chwalibog, A.; Sawosz, E.; Hotowy, A.; Szeliga, J.; Mitura, S.; Mitura, K.; Grodzik, M.; Orlowski, P.; Sokolowska, A. Visualization of interaction between inorganic nanoparticles and bacteria or fungi. Int. J. Nanomed. 2010, 5, 1085-1094. [CrossRef]

82. Sambhy, V.; MacBride, M.M.; Peterson, B.R.; Sen, A. Silver bromide nanoparticle/polymer composites: Dual action tunable antimicrobial materials. J. Am. Chem. Soc. 2006, 128, 9798-9808. [CrossRef]

83. Holt, K.B.; Bard, A.J. Interaction of silver(I) ions with the respiratory chain of Escherichia coli: Anm electrochemical and scanning electrochemical microscopy study of the antimicrobial mechanism of micromolar Ag. Biochemistry 2005, 44, 13214-13223. [CrossRef]

84. Lok, C.-N.; Ho, C.-M.; Chen, R.; He, Q.-Y.; Yu, W.-Y.; Sun, H.; Tam, P.K.-H.; Chiu, J.-F.; Che, C.-M. Proteomic analysis of the mode of antibacterial action of silver nanoparticles. J. Proteome Res. 2006, 5, 916-924. [CrossRef]

85. van Grieken, R.; Marugán, J.; Sordo, C.; Martínez, P.; Pablos, C. Photocatalytic inactivation of bacteria in water using suspended and immobilized silver-TiO ${ }_{2}$. Appl. Catal. B Environ. 2009, 93, 112-118. [CrossRef]

86. Akhavan, $\mathrm{O}$. Lasting antibacterial activities of $\mathrm{Ag}-\mathrm{TiO}_{2} / \mathrm{Ag} / \mathrm{a}-\mathrm{TiO}_{2}$ nanocomposite thin film photocatalysts under solar light irradiation. J. Colloid Interface Sci. 2009, 336, 117-124. [CrossRef] [PubMed]

87. Li, M.; Noriega-Trevino, M.E.; Nino-Martinez, N.; Marambio-Jones, C.; Wang, J.; Damoiseaux, R.; Ruiz, F.; Hoek, E.M.V. Synergistic bactericidal activity of $\mathrm{Ag}-\mathrm{TiO}_{2}$ nanoparticles in both light and dark conditions. Environ. Sci. Technol. 2011, 45, 8989-8995. [CrossRef] [PubMed]

88. Lin, W.C.; Chen, C.N.; Tseng, T.T.; Wei, M.H.; Hsieh, J.H.; Tseng, W.J. Micellar layer-by-layer synthesis of $\mathrm{TiO}_{2} / \mathrm{Ag}$ hybrid particles for bactericidal and photocatalytic activities. J. Eur. Ceram. Soc. 2010, 30, $2849-2857$. [CrossRef]

89. Liga, M.V.; Bryant, E.L.; Colvin, V.L.; Li, Q. Virus inactivation by silver doped titanium dioxide nanoparticles for drinking water treatment. Water Res. 2011, 45, 535-544. [CrossRef]

90. Tian, Y.; Qi, J.; Zhang, W.; Cai, Q.; Jiang, X. Facile, one-pot synthesis, and antibacterial activity of mesoporous silica nanoparticles decorated with well-dispersed silver nanoparticles. Appl. Mater. Interfaces 2014, 6, 12038-12045. [CrossRef]

91. Su, H.L.; Chou, C.C.; Hung, D.J.; Lin, S.H.; Pao, I.C.; Lin, J.H.; Huang, F.L.; Dong, R.X.; Lin, J.J. The disruption of bacterial membrane integrity through ROS generation induced by nanohybrids of silver and clay. Biomaterials 2009, 30, 5979-5987. [CrossRef]

92. Galdiero, S.; Falanga, A.; Vitiello, M.; Cantisani, M.; Marra, V.; Galdiero, M. Silver nanoparticles as potential antiviral agents. Molecules 2011, 16, 8894-8918. [CrossRef]

93. Speshock, J.L.; Murdock, R.C.; Braydich-Stolle, L.K.; Schrand, A.M.; Hussain, S.M. Interaction of silver nanoparticles with HIV-1. J. Nanobiotechnol. 2010, 8, 19-27. [CrossRef]

94. Sunada, K.; Minoshima, M.; Hashimoto, K. Highly efficient antiviral and antibacterial activities of solid-state cuprous compounds. J. Hazard. Mater. 2012, 235, 265-270. [CrossRef] 
95. Deng, C.H.; Gong, J.L.; Zeng, G.M.; Zhang, P.; Song, B.; Zhang, X.G.; Liu, H.Y.; Huan, S.Y. Graphene sponge decorated with copper nanoparticles as a novel bactericidal filter for inactivation of Escherichia coli. Chemosphere 2017, 184, 347-357. [CrossRef] [PubMed]

96. Dankovich, T.A.; Gray, D.G. Bactericidal paper impregnated with silver nanoparticles for emergency water disinfection. Environ. Sci. Technol. 2011, 45, 1992-1998. [CrossRef]

97. Jafari, A.; Pourakbar, L.; Farhadi, K.; Mohamadgolizad, L.; Goosta, Y. Biological synthesis of silver nanoparticles and evaluation of antibacterial and antifungal properties of silver and copper nanoparticles. Turk. J. Biol. 2015, 39, 556-561. [CrossRef]

98. Amin, R.M.; Mohamed, M.B.; Ramadan, M.A.; Verwanger, T.; Krammer, B. Rapid and sensitive microplate assay for screening the effect of silver and gold nanoparticles on bacteria. Nanomedicine 2009, 4, 637-643. [CrossRef] [PubMed]

99. Zhang, W.; Li, Y.; Niu, J.; Chen, Y. Photogeneration of reactive oxygen species on uncoated silver, gold, nickel, and silicon nanoparticles and their antibacterial effects. Langmuir 2013, 29, 4647-4651. [CrossRef]

100. Zheng, K.; Setyawati, M.I.; Leong, D.T.; Xie, J. Antimicrobial gold nanoclusters. ACS Nano 2017, 11, $6904-6910$. [CrossRef]

101. Ratte, H.T. Bioaccumulation and toxicity of silver compounds: A review. Environ. Toxicol. Chem. 1999, 18, 89-108. [CrossRef]

102. Rai, A.; Prabhune, A.; Perry, C.C. Antibiotic mediated synthesis of gold nanoparticles with potent antimicrobial activity and their application in antimicrobial coatings. J. Mater. Chem. 2010, 20, 6789-6798. [CrossRef]

103. Badwaik, V.D.; Vangala, L.M.; Pender, D.S.; Willis, C.B.; Aguilar, Z.P.; Gonzalez, M.S.; Paripelly, R.; Dakshinamurthy, R. Size-dependent antimicrobial properties of sugarencapsulated gold nanoparticles synthesized by a green method. Nanoscale Res. Lett. 2012, 7, 1-11. [CrossRef]

104. Cui, Y.; Zhao, Y.; Tian, Y.; Zhang, W.; Lü, X.; Jiang, X. The molecular mechanism of action of bactericidal gold nanoparticles on Escherichia coli. Biomaterials 2012, 33, 2327-2333. [CrossRef]

105. Ahmad, T.; Wani, I.A.; Lone, I.H.; Ganguly, A.; Manzoor, N.; Ahmad, A.; Ahmed, J.; Al-Shihri, A.S. Antifungal activity of gold nanoparticles prepared by solvothermal method. Mater. Res. Bull. 2013, 48, 12-20. [CrossRef]

106. Baram-Pinto, D.; Shukla, S.; Gedanken, A.; Sarid, R. Inhibition of HSV-1 attachment, entry, and cell-to-cell spread by functionalized multivalent gold nanoparticles. Small 2010, 6, 1044-1050. [CrossRef] [PubMed]

107. Kubacka, A.; Ferrer, M.; Martínez-Arias, A.; Fernández-García, M. Ag promotion of $\mathrm{TiO}_{2}$-anatase disinfection capability: Study of Escherichia coli inactivation. Appl. Catal. B Environ. 2008, 84, 87-93. [CrossRef]

108. Mai, L.; Wang, D.; Zhang, S.; Xie, Y.; Huang, C.; Zhang, Z. Synthesis and bactericidal ability of Ag/TiO 2 composite films deposited on titanium plate. Appl. Surf. Sci. 2010, 257, 974-978. [CrossRef]

109. Castro, C.A.; Osorio, P.; Sienkiewicz, A.; Pulgarin, C.; Centeno, A.; Giraldo, S.A. Photocatalytic production of ${ }^{1} \mathrm{O}_{2}$ and $\mathrm{OH}$ mediated by silver oxidation during the photoinactivation of Escherichia coli with $\mathrm{TiO}_{2}$. J. Hazard. Mater. 2012, 211, 172-181. [CrossRef]

110. Baghriche, O.; Rtimi, S.; Pulgarin, C.; Sanjines, R.; Kiwi, J. Innovative $\mathrm{TiO}_{2} / \mathrm{Cu}$ nanosurfaces inactivating bacteria in the minute range under low-intensity actinic light. ACS Appl. Mater. Interfaces 2012, 4, 5234-5240. [CrossRef]

111. Rtimi, S.; Giannakis, S.; Sanjines, R.; Pulgarin, C.; Bensimon, M.; Kiwi, J. Insight on the photocatalytic bacterial inactivation by co-sputtered $\mathrm{TiO}_{2}-\mathrm{Cu}$ in aerobic and anaerobic conditions. Appl. Catal. B Environ. 2016, 182, 277-285. [CrossRef]

112. Liu, L.; Yang, W.; Li, Q.; Gao, S.; Shang, J.K. Synthesis of $\mathrm{Cu}_{2} \mathrm{O}$ nanospheres decorated with $\mathrm{TiO}_{2}$ nanoislands, their enhanced photoactivity and stability under visible light illumination, and their post-illumination catalytic memory. ACS Appl. Mater. Interfaces 2014, 6, 5629-5639. [CrossRef]

113. Stentzel, S.; Teufelberger, A.; Nordengrün, M.; Kolata, J.; Schmidt, F.; van Crombruggen, K.; Michalik, S.; Kumpfmüller, J.; Tischer, S.; Schweder, T.; et al. Staphylococcal serine protease-like proteins are pacemakers of allergic airway reactions to Staphylococcus aureus. J. Allergy Clin. Immunol. 2017, 139, 492-500. [CrossRef]

114. Kowalska, E.; Wei, Z.; Karabiyik, B.; Janczarek, M.; Endo, M.; Markowska-Szczupak, A.; Remita, H.; Ohtani, B. Silver modified titania with enhanced photocatalytic and antimicrobial properties under UV and visible light irradiation. Cata. Today 2015, 252, 136-142. [CrossRef]

115. Endo, M.; Wei, Z.; Wang, K.; Karabiyik, B.; Yoshiiri, K.; Rokicka, P.; Ohtani, B.; Markowska-Szczupak, A.; Kowalska, E. Noble metal-modified titania with visible-light activity for the decomposition of microorganisms. Beilstein J. Nanotechnol. 2018, 9, 829-841. [CrossRef] 
116. Hou, Y.; Li, X.; Zhao, Q.; Chen, G.; Raston, C.L. Role of hydroxyl radicals and mechanism of escherichia coli inactivation on $\mathrm{Ag} / \mathrm{AgBr} / \mathrm{TiO}_{2}$ nanotube array electrode under visible light irradiation. Environ. Sci. Technol. 2012, 46, 4042-4050. [CrossRef] [PubMed]

117. Wei, Z.; Endo, M.; Wang, K.; Charbit, E.; Markowska-Szczupak, A.; Ohtani, B.; Kowalska, E. Noble metal-modified octahedral anatase titania particles with enhanced activity for decomposition of chemical and microbiological pollutants. Chem. Eng. J. 2017, 318, 121-134. [CrossRef] [PubMed]

118. Ye, J.; Cheng, H.; Li, H.; Yang, Y.; Zhang, S.; Rauf, A.; Zhao, Q.; Ning, G. Highly synergistic antimicrobial activity of spherical and flower-like hierarchical titanium dioxide/silver composites. J. Colloid Interface Sci. 2017, 504, 448-456. [CrossRef] [PubMed]

119. Rtimi, S.; Baghriche, O.; Sanjines, R.; Pulgarin, C.; Bensimon, M.; Kiwi, J. TiON and TiON-Ag sputtered surfaces leading to bacterial inactivation under indoor actinic light. J. Photochem. Photobiol. A Chem. 2013, 256, 52-63. [CrossRef]

120. Veréb, G.; Manczinger, L.; Bozsó, G.; Sienkiewicz, A.; Forró, L.; Mogyorósi, K.; Hernádi, K.; Dombi, A. Comparison of the photocatalytic efficiencies of bare and doped rutile and anatase $\mathrm{TiO}_{2}$ photocatalysts under visible light for phenol degradation and E. coli inactivation. Appl. Catal. B Environ. 2013, 129, 566-574. [CrossRef]

121. Swetha, S.; Kumari Singh, M.; Minchitha, K.U.; Geetha Balakrishna, R. Elucidation of cell killing mechanism by comparative analysis of photoreactions on different types of bacteria. Photochem. Photobiol. 2012, 88, 414-422. [CrossRef]

122. Endo-Kimura, M. A Mechanistic Study on Noble Metal-Modified Titania Photocatalysts for Inactivation of Bacteria and Fungi. Ph.D. Thesis, Hokkaido University, Sapporo, Japan, 2019.

123. Endo-Kimura, M.; Wang, K.; Wei, Z.; Juodkazis, S.; Markowska-Szczupak, A.; Ohtani, B.; Kowalska, E. Surface-Plasmon-Driven Inactivation of Microorganisms on Mono- and Bi-Metal (Au/Ag)-Modified Titania: A Mechanistic Study. (under preparation).

124. Zielińska, A.; Kowalska, E.; Sobczak, J.W.; Łacka, I.; Gazda, M.; Ohtani, B.; Hupka, J.; Zaleska, A. Silver-doped $\mathrm{TiO}_{2}$ prepared by microemulsion method: Surface properties, bio- and photoactivity. Sep. Purif. Technol. 2010, 72, 309-318. [CrossRef]

125. Kowal, K.; Wysocka-Król, K.; Kopaczyńska, M.; Dworniczek, E.; Franiczek, R.; Wawrzyńska, M.; Vargová, M.; Zahoran, M.; Rakovský, E.; Kuš, P.; et al. In situ photoexcitation of silver-doped titania nanopowders for activity against bacteria and yeasts. J. Colloid Interface Sci. 2011, 362, 50-57. [CrossRef]

126. Wysocka, I.; Markowska-Szczupak, A.; Szweda, P.; Ryl, J.; Endo-Kimura, M.; Kowalska, E.; Nowaczyk, G.; Zielińska-Jurek, A. Gas-phase removal of indoor volatile organic compounds and airborne microorganisms over mono- and bimetal-modified ( $\mathrm{Pt}, \mathrm{Cu}, \mathrm{Ag}$ ) titanium(IV) oxide nanocomposites. Indoor Air. 2019, 29, 979-992. [CrossRef] [PubMed]

127. Mendez-Medrano, M.G.; Kowalska, E.; Endo, M.; Wang, K.; Bahena, D.; Rodriguez-Lopez, J.L.; Remita, H. Inhibition of fungal growth using modified $\mathrm{TiO}_{2}$ with core@shell structure of Ag@CuO clusters. ACS Appl. Bio. Mater. 2019, 2, 5626-5633. [CrossRef]

128. Dankovich, T.A.; Smith, J.A. Incorporation of copper nanoparticles into paper for point-of-use water purification. Water Res. 2014, 63, 245-251. [CrossRef] [PubMed]

129. Endo, M.; Janczarek, M.; Wei, Z.; Wang, K.; Mrkowska-Szczupak, M.; Ohtani, B.; Kowalska, E. Bactericidal properties of plasmonic photocatalysts composed of noble metal nanoparticles on faceted anatase titania. J. Nanosci. Nanotechnol. 2019, 19, 442-452. [CrossRef]

130. He, W.; Huang, H.; Yan, J.; Zhu, J. Photocatalytic and antibacterial properties of $\mathrm{Au}-\mathrm{TiO}_{2}$ nanocomposite on monolayer graphene: From experiment to theory. J. Appl. Phys. 2013, 114, 204701. [CrossRef]

131. Noimark, S.; Page, K.; Bear, J.C.; Sotelo-Vazquez, C.; Quesada-Cabrera, R.; Lu, Y.; Allan, E.; Darr, J.A.; Parkin, I.P. Functionalised gold and titania nanoparticles and surfaces for use as antimicrobial coatings. Faraday Discuss. 2014, 175, 273-287. [CrossRef]

132. Wang, G.; Feng, H.; Gao, A.; Hao, Q.; Jin, W.; Peng, X.; Li, W.; Wu, G.; Chu, P.K. Extracellular Electron Transfer from Aerobic Bacteria to $\mathrm{Au}$-Loaded $\mathrm{TiO}_{2}$ Semiconductor without Light: A New Bacteria-Killing Mechanism Other than Localized Surface Plasmon Resonance or Microbial Fuel Cells. ACS Appl. Mater. Interfaces 2016, 8, 24509-24516. [CrossRef] 
133. Ren, W.; Yan, Y.; Zeng, L.; Shi, Z.; Gong, A.; Schaaf, P.; Wang, D.; Zhao, J.; Zou, B.; Yu, H.; et al. A near infrared light triggered hydrogenated black $\mathrm{TiO}_{2}$ for cancer photothermal therapy. Adv. Healthc. Mater. 2015, 4, 1526-1536. [CrossRef]

134. Mou, J.; Lin, T.; Huang, F.; Chen, H.; Shi, J. Black titania-based theranostic nanoplatform for single NIR laser induced dual-modal imaging-guided PTT/PDT. Biomaterials 2016, 84, 13-24. [CrossRef]

135. Han, X.; Huang, J.; Jing, X.; Yang, D.; Lin, H.; Wang, Z.; Li, P.; Chen, Y. Oxygen-deficient black titania for synergistic/enhanced sonodynamic and photoinduced cancer therapy at near infrared-II biowindow. ACS Nano 2018, 12, 4545-4555. [CrossRef]

136. Mou, J.; Lin, T.; Huang, F.; Shi, J.; Chen, H. A new green titania with enhanced NIR absorption for mitochondria-targeted cancer therapy. Theranostics 2017, 7, 1531-1542. [CrossRef] [PubMed]

137. Wan, H.Y.; Chen, J.L.; Yu, X.Y.; Zhu, X.M. Titania-coated gold nanorods as an effective carrier for gambogic acid. RSC Adv. 2017, 7, 49518-49525. [CrossRef]

138. Ali, M.R.K.; Wu, Y.; Tang, Y.; Xiao, H.; Chen, K.; Han, T.; Fang, N.; Wu, R.; El-Sayed, M.A. Targeting cancer cell integrins using gold nanorods in photothermal therapy inhibits migration through affecting cytoskeletal proteins. Proc. Natl. Acad. Sci. USA 2017, 114, E5655-E5663. [CrossRef] [PubMed]

139. Seo, J.H.; Jeon, W.I.; Dembereldorj, U.; Lee, S.Y.; Joo, S.W. Cytotoxicity of serum protein-adsorbed visible-light photocatalytic Ag/AgBr/TiO 2 nanoparticles. J. Hazard. Mater. 2011, 198, 347-355. [CrossRef]

140. Lucky, S.S.; Muhammad Idris, N.; Li, Z.; Huang, K.; Soo, K.C.; Zhang, Y. Titania coated upconversion nanoparticles for near-infrared light triggered photodynamic therapy. ACS Nano 2015, 9, 191-205. [CrossRef] [PubMed]

141. Jain, P.K.; Huang, X.; El-Sayed, I.H.; El-Sayed, M.A. Noble metals on the nanoscale: Optical and photothermal properties and some applications in imaging, sensing, biology, and medicine. Acc. Chem. Res. 2008, 41, 1578-1586. [CrossRef] [PubMed]

142. Xu, J.; Sun, Y.; Zhao, Y.; Huang, J.; Chen, C.; Jiang, Z. Photocatalytic inactivation effect of gold-doped TiO 2 $\left(\mathrm{Au} / \mathrm{TiO}_{2}\right)$ nanocomposites on human colon carcinoma LoVo cells. Int. J. Photoenergy 2007, 21. [CrossRef]

143. Yuan, Y.; Chen, S.; Paunesku, T.; Gleber, S.C.; Liu, W.C.; Doty, C.B.; Mak, R.; Deng, J.; Jin, Q.; Lai, B.; et al. Epidermal growth factor receptor targeted nuclear delivery and high-resolution whole cell x-ray imaging of $\mathrm{Fe}_{3} \mathrm{O}_{4} @ \mathrm{TiO}_{2}$ nanoparticles in cancer cells. ACS Nano 2013, 7, 10502-10517. [CrossRef]

144. Rozhkova, E.A.; Ulasov, I.; Lai, B.; Dimitrijevic, N.M.; Lesniak, M.S.; Rajh, T. A High-performance nanobio photocatalyst for targeted brain cancer therapy. Nano Lett. 2009, 9, 3337-3342. [CrossRef]

145. Tong, L.; Zhao, Y.; Huff, T.B.; Hansen, M.N.; Wei, A.; Cheng, J.X. Gold Nanorods Mediate Tumor Cell Death by Compromising Membrane Integrity. Adv. Mater. 2007, 19, 3136-3141. [CrossRef]

146. Ali, M.R.K.; Wu, Y.; Ghosh, D.; Do, B.H.; Chen, K.; Dawson, M.R.; Fang, N.; Sulchek, T.A.; El-Sayed, M.A. Nuclear membrane-targeted gold nanoparticles inhibit cancer cell migration and invasion. ACS Nano 2017, 11, 3716-3726. [CrossRef] [PubMed]

(C) 2020 by the authors. Licensee MDPI, Basel, Switzerland. This article is an open access article distributed under the terms and conditions of the Creative Commons Attribution (CC BY) license (http://creativecommons.org/licenses/by/4.0/). 